\title{
Bioreducible cross-linked core polymer micelles enhance in vitro activity of methotrexate in breast cancer cells
}

Received 00th December 2016, Accepted 00th January 20xx

DOI: $10.1039 / \times 0 \times x 00000 x$

www.rsc.org/

\author{
Muhammad Gulfam, ${ }^{\mathrm{a}, \mathrm{b}}$ Teresa Matini, ${ }^{\mathrm{a}}$ Patrícia F. Monteiro ${ }^{\mathrm{a}}$, Raphaël Riva, ${ }^{\mathrm{b}}$ Hilary Collins, ${ }^{\mathrm{a}}$ Keith \\ Spriggs, ${ }^{a}$ Steven M. Howdle, ${ }^{c}$ Christine Jérôme ${ }^{\mathrm{b}}$ and Cameron Alexander ${ }^{\mathrm{a}^{*}}$
}

Polymer micelles have emerged as promising carriers for controlled release applications, however, several limitations of micelle-based drug delivery have also been reported. To address these issues, we have synthesized a functional biodegradable and cytocompatible block copolymer based on methoxypoly(ethyleneglycol)- $b$-poly $(\varepsilon$-caprolactone-co- $\alpha$ azido- $\varepsilon$-caprolactone) (mPEG- $b$-poly $\left(\varepsilon C L-c o-\alpha N_{3} \varepsilon C L\right)$ ) as a precursor of reduction sensitive core-crosslinked micelles. The synthesized polymer was formulated as micelles using a dialysis method and loaded with the anti-inflammatory and anticancer drug methotrexate (MTX). The micellar cores were subsequently crosslinked at their pendant azides by a redoxresponsive bis(alkyne). The size distributions and morphology of the polymer micelles were assessed using dynamic light scattering (DLS) and transmission electron microscopy, and drug release assays were performed under simplified (serum free) physiological and reductive conditions. Cellular uptake studies in human breast cancer cells were performed using Oregon-green loaded core-crosslinked micelles. The MTX-loaded core-crosslinked micelles were assessed for their effects on metabolic activity in human breast cancer (MCF-7) cells by evaluating the reduction of the dye MTT 3-(4,5dimethylthiazol-2-yl)-2,5-diphenyltetrazolium bromide. The apoptosis inducing potential of MTX-loaded core-crosslinked micelles was analysed using Hoechst/propidium iodide (PI) and annexin-V/PI assays. The data from these experiments indicated that drug release from these cross-linked micelles can be controlled and that the redox-responsive micelles are more effective carriers for MTX than non-crosslinked analogues and the free drug in the cell-lines tested.

\section{Introduction}

Block copolymer micelles and vesicles have been extensively investigated for site-specific drug delivery and applications which require controlled release of active agents. ${ }^{1-4}$ Although delivery of drugs via micellar carriers offers several advantages over administration of free drugs, for example prolonged circulation time, improved bioavailability, enhanced accumulation in disease sites, and fewer side effects, ${ }^{5}$ some limitations of polymer micelles for delivery have also been reported.6, 7 These include low stability in vivo, poor penetration, modest accumulation in target tissues and premature payload discharge in the bloodstream due to inadequate control over drug release. ${ }^{8-10}$

To overcome such limitations, stimuli-responsive or smart polymeric nanocarriers have been developed. ${ }^{11}, 12$ These materials are designed to release payloads in response to internal or external stimuli such as light, magnetic fields, temperature, enzymes, redox-potential, and reactive oxygen species. ${ }^{13,14}$ Of particular interest are bioresponsive materials which can take advantage of disease-specific stimuli to trigger generation of a diagnostic signal or release of a drug. ${ }^{15}$ Variations in redox potential and enzyme expression are important factors in pathological conditions which might be exploited by bioresponsive polymers. For example, it has been reported that the reducing potential inside several cancer cells

\footnotetext{
School of Pharmacy, University of Nottingham, NG7 2RD, UK. E-mail: cameron.alexander@nottingham.ac.uk.Tel: +44 (0)115 8467678

b. Center for Education and Research on Macromolecules (CERM), University of Liège, Sart-Tilman, B6, 4000 Liège, Belgium.

School of Chemistry, University of Nottingham, NG7 2RD, UK.
}

Electronic Supplementary Information (ESI) available: See DOI: 10.1039/x0xx00000x (e.g. human breast, prostate, colon and pancreatic cancer cells) ${ }^{16}$ is considerably higher (approximately $100-1000$ times) than found in the extracellular environment and bloodstream. ${ }^{17,} 18$ Although redox states in cancer cells are controlled by complex and variable parameters, ${ }^{19}$ nevertheless, the ranges of redox potential are sufficient that polymers can in principle be designed to respond differentially in specific cells for tumour selective drug delivery.

The most-established chemistries for inducing reductive responses into polymers are those based on disulfide linkages ${ }^{20}$. These are relatively stable in normal extracellular environments but undergo rapid cleavage in the presence of reducing agents and reactive thiols, such as glutathione (GSH), when inside intracellular components. ${ }^{13}, 21$ The disulfide links can be incorporated in the backbone of a polymer or in a side chain, or as a crosslinker inside a nanocarrier by using appropriate functional initiators, monomers or chain transfer agents. ${ }^{22-25}$ Disulfide units can also be used to conjugate therapeutic agents to polymer side chains, allowing for directly triggered drug release. ${ }^{26}$. Various types of disulfide can be used to crosslink micelles internally, ${ }^{27}$ either in the core, ${ }^{9}$ or at the shell. ${ }^{28}$ Although shell crosslinked micelles can offer better stability along with higher drug loading, however, a challenge in preparation of shell-crosslinked micelles is the need for highly dilute conditions to circumvent undesired inter-micellar crosslinking, therefore making this route difficult for large-scale micellar preparation. ${ }^{29}$ Moreover, the inter-micellar crosslinking in shell cross-linked micelles may also cause the agglomeration of nanocarriers into larger particles leading to system instability and poor pharmacokinetic properties.

To overcome these limitations, reduction sensitive corecrosslinked micelles have been developed. Generally, these systems are designed from amphiphilic block copolymers that 
contain functional moieties (e.g. carboxylic acid, hydrazide, lipoyl, dithiopyridine, thiol and alkynyl) in the hydrophobic block as pendent or end-capped groups. ${ }^{30}$ Although many of these micelles have demonstrated good stability and 'stealth' properties, $^{31}$ the hydrophobic cores have largely been based on non-degradable polymers such as polyacrylamide or polyacrylate. 32 , 33 Therefore, analogous micelles composed entirely of biologically inert and/or biodegradable polymers would be better candidates for clinical use. ${ }^{34}$

To address these issues, we have synthesized a functional biodegradable and biocompatible block copolymer based on methoxypoly(ethyleneglycol)- $b$-poly( $\varepsilon$-caprolactone-co- $\alpha$ -

azido- $\varepsilon$-caprolactone) (mPEG- $b$-poly $\left.\left(\varepsilon \mathrm{CL}-c o-\alpha \mathrm{N}_{3} \varepsilon \mathrm{CL}\right)\right)$ as precursor of reduction sensitive core-crosslinked micelles. The synthesized block copolymer was characterized by ${ }^{1} \mathrm{H} \mathrm{NMR},{ }^{13} \mathrm{C}$ NMR, FT-IR and size exclusion chromatography (SEC). Micelles were prepared using a dialysis method and methotrexate as a representative drug was loaded into the hydrophobic core of the reactive micelles.

Methotrexate (MTX) was chosen for these studies as it has been used against various malignancies including breast cancer, lung cancer, head and neck cancer, Hodgkin's disease, nonHodgkin's lymphoma, osteosarcoma, and childhood acute lymphoblastic leukaemia. Although MTX has proven very effective in treating certain types of tumours, various dose related side effects including acute and chronic hepatotoxicity, bone marrow suppression, interstitial pneumonitis, nephrotoxicity, and leukopenia, have been reported. ${ }^{35}$ Furthermore, poor aqueous solubility $(0.01 \mathrm{mg} / \mathrm{mL}$, pKa; 4.7 5.5), low permeability and the short circulation half-life (2-10 hours) of the free acid form of MTX are major barriers in developing therapeutically successful formulations. ${ }^{36,37}$

In addition, while methotrexate disodium salt exhibits good aqueous solubility and can be routinely administered through the oral route, plasma MTX concentrations after oral administration can vary significantly due to interpatient differences in the rate of absorption. ${ }^{38}$ Moreover, uptake of orally administered MTX through the gastrointestinal tract is mainly mediated via a saturable transporter, the reduced folate carrier (RFC). Accordingly, the bioavailability of orally administered MTX cannot increase upon saturation of the RFC and higher doses are no more effective. ${ }^{39}$

In order to evaluate our carrier system for more predictable and effective dosing of MTX, the drug was loaded in the free acid form into the core of micelles. Crosslinking at the micellar cores was achieved using a bis(alkyne ethyl) disulfide (Scheme 1). The size distributions and morphologies of the resultant corecrosslinked micelles were assessed using dynamic light scattering (DLS) and transmission electron microscopy. Drug release studies were performed under simulated physiological and reductive conditions. Cellular uptake studies in human breast cancer (MCF7) cells were performed using Oregon-green loaded core-crosslinked micelles. The MTX-loaded corecrosslinked micelles were assessed for their effects on metabolic activity in the MCF7 cells by MTT assays. The apoptosis inducing potential of MTX-loaded core-crosslinked micelles was analysed using the Hoechst/PI method and was further probed by annexin-V/PI assays. The data from these assays indicate that drug release from these cross-linked micelles can be controlled and that the redox-responsive micelles are more effective carriers for MTX than noncrosslinked analogues and MTX free acid in the cell-lines tested.

\section{Experimental section}

\section{Materials}

All chemicals were used as obtained without additional purification unless otherwise stated. 2-chlorocyclohexanone (98\%), 3-chloroperoxybenzoic acid (mCPBA $70 \%$ ), monomethoxy poly(ethylene glycol) (mPEG, $M n-5000 \mathrm{~g} / \mathrm{mol}$ ), $\varepsilon$ caprolactone (97\%), tin(II) 2-ethylhexanoate (92.5-100\%), sodium azide ( $\geq 99.5 \%$ ), copper (II) sulfate (99.9\%), ascorbic acid sodium salt $(\geq 98 \%)$, pyrene ( $\geq 99 \%), \quad N-(3-$ dimethylaminopropyl)- $\mathrm{N}^{\prime}$-ethylcarbodiimide hydrochloride (EDAC, $99 \%$ ), 4-(dimethylamino) pyridine (DMAP, $\geq 99 \%$ ), 2hydroxyethyl disulfide (90\%), 4-pentynoic acid (95\%), 4fluororesorcinol (97\%), 1,2,4-benzenetricarboxylic anhydride (97\%), ethylenediaminetetraacetic acid disodium salt dihydrate (EDTA, $99 \%$ ), dithiothreitol (DTT, $98 \%$ ), and all deuterated solvents were purchased form Sigma-Aldrich. Methotrexate $(\geq$ $98 \%)$, was obtained from VWR International. Cells from a human breast cancer cell line (MCF7) were obtained from American Type Cell Culture Collection (ATCC). Dulbecco's Modified Eagle Medium (DMEM), fetal bovine serum, Lglutamine, trypsin-EDTA solution $(10 \times)$, 3-(4,5-Dimethyl-2thiazolyl)-2,5-diphenyl-2H-tetrazolium bromide (MTT, $97.5 \%$ ) and annexin V-FITC apoptosis detection kit was purchased from Sigma-Aldrich. Propidium iodide and Hoechst 33342 stains were purchased from Fisher Scientific UK. CellMask Deep Red plasma membrane stain was procured from Invitrogen (Thermo Fisher Scientific).

\section{Methods}

Synthesis of $\alpha$-chloro- $\varepsilon$-caprolactone ( $\alpha \mathrm{Cl} \varepsilon \mathrm{CL}$ ) 


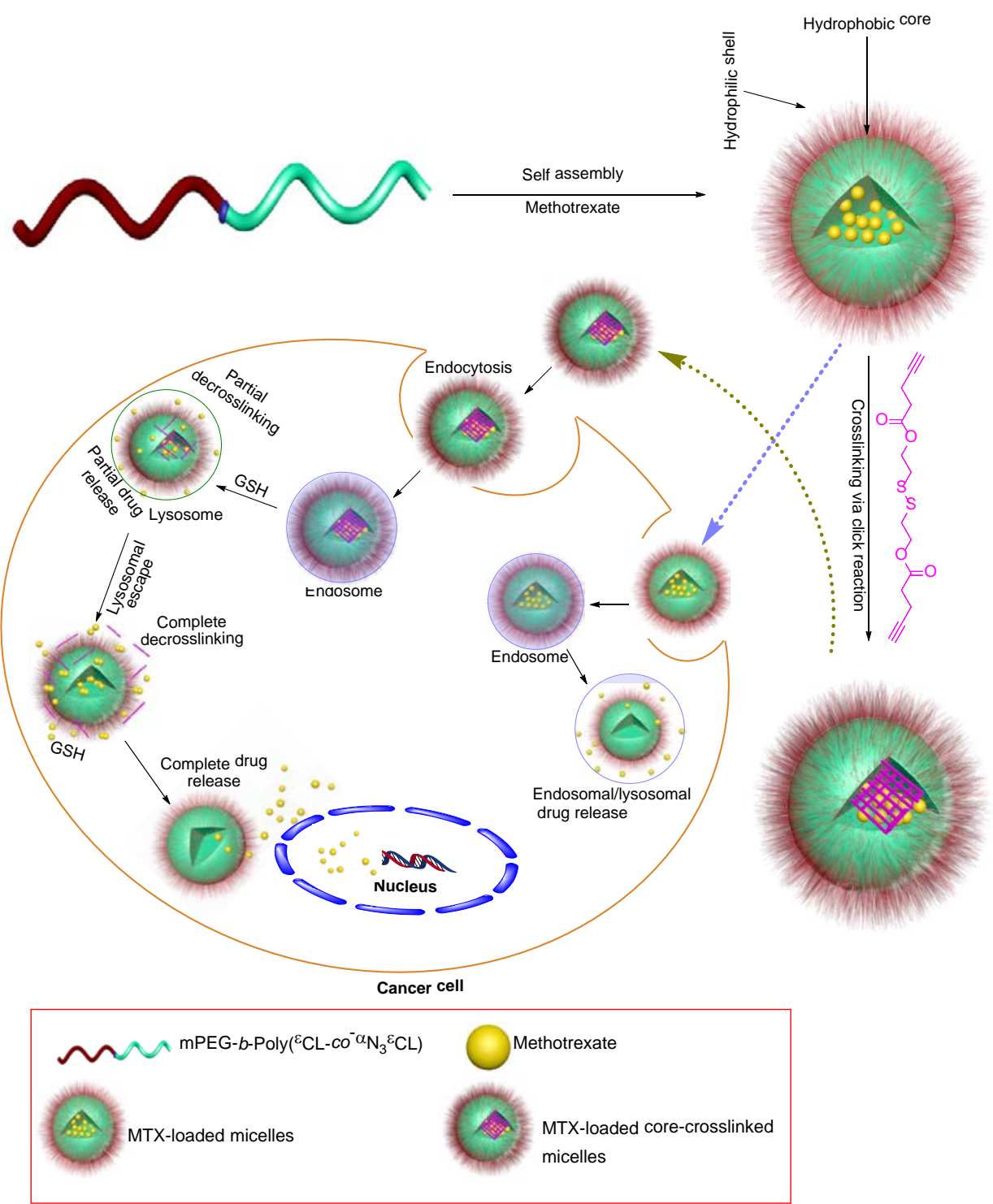

Scheme 1 - Outline illustration for the preparation of MTX-loaded redox-responsive reversibly core-crosslinked micelles, intracellular uptake and mechanism of drug release.

The $\alpha \mathrm{Cl} \varepsilon \mathrm{CL}$ monomer was synthesized by oxidation of 2chlorocyclohexanone with meta-chloroperoxybenzoic acid (mCPBA). 2-Chlorocyclohexanone (5 g, $37.5 \mathrm{mmol}$ ) was dissolved in $50 \mathrm{~mL}$ dichloromethane in a round bottom flask and the solution was cooled to $0{ }^{\circ} \mathrm{C}$ using an ice bath. Afterwards, $10 \mathrm{~g}(40.5 \mathrm{mmol})$ of $\mathrm{mCPBA}$ was carefully introduced into the reaction mixture within 10 minutes. The reaction mixture was stirred at room temperature for 96 hours, and was subsequently cooled to $-20^{\circ} \mathrm{C}$. After filtration, the filtrate was washed (three times) with $100 \mathrm{~mL}$ saturated solutions of $\mathrm{Na}_{2} \mathrm{~S}_{2} \mathrm{O}_{3}$, and then with $\mathrm{NaHCO}_{3}$, and once with saturated solution of $\mathrm{NaCl}(100 \mathrm{~mL})$. Finally, the organic phase was washed 3 times with $100 \mathrm{~mL}$ deionized $\mathrm{H}_{2} \mathrm{O}$. After drying over magnesium sulfate, the organic phase was filtered again, and the organic solvent was removed by a rotary evaporator to obtain a pale viscous liquid. Finally, the product was purified by silica gel column chromatography with solvents of analytical purity as mobile phase (hexane: ethyl acetate $9: 2, R_{f} 0.36$ ) to obtain $\alpha \mathrm{Cl} \varepsilon \mathrm{CL}$ ( $3.50 \mathrm{~g}, 70 \%$ yield). ${ }^{1} \mathrm{H}$ NMR $\left(400 \mathrm{MHz}, \mathrm{CDCl}_{3}\right) \delta$ (ppm): 4.85-4.81 (COCHCl, t, $1 \mathrm{H})$, 4.69-4.63 $\left(\mathrm{CH}_{2} \mathrm{CH}_{2} \mathrm{O}, \mathrm{m}, 1 \mathrm{H}\right)$, 4.29-4.23 $\left(\mathrm{CH}_{2} \mathrm{C}_{2} \mathrm{O}, \mathrm{m}, 1 \mathrm{H}\right), 2.23-1.77\left(\mathrm{ClCHC}_{2} \mathrm{C}_{2} \mathrm{C}_{2}, \mathrm{~m}, 6 \mathrm{H}\right)$.

\section{Synthesis of mPEG- $b$-poly $(\varepsilon \mathrm{CL}-c o-\alpha \mathrm{Cl} \varepsilon \mathrm{CL})$}

Briefly, $0.5 \mathrm{~g} \mathrm{mPEG}(0.1 \mathrm{mmol})$ and $0.104 \mathrm{~g} \alpha \mathrm{Cl} \varepsilon \mathrm{CL}(0.7 \mathrm{mmol})$ were dissolved in anhydrous toluene and dried by azeotropic distillations (3 times) in a glass reactor. Afterwards, $0.4 \mathrm{~g} \varepsilon \mathrm{CL}$ ( $3.5 \mathrm{mmol}$, dried over $\mathrm{CaH}_{2}$ and distilled under reduced pressure prior to use) was introduced via a rubber septum using a glass syringe and the mixture was heated to $50{ }^{\circ} \mathrm{C}$ and stirred for 15 minutes, until a homogeneous mixture was obtained. SnOct $_{2}$ (14 mg, $0.034 \mathrm{mmol}$, dissolved in $\mathrm{CH}_{2} \mathrm{Cl}_{2}$ ) was finally introduced (under nitrogen) and the reaction was stirred at $100{ }^{\circ} \mathrm{C}$ for 24 hours. Finally, the copolymer was dissolved in $5 \mathrm{~mL} \mathrm{CH}{ }_{2} \mathrm{Cl}_{2}$ and was precipitated in anhydrous diethyl ether. The synthesized 
copolymer was dried in vacuo and characterized by NMR, SEC, and FT-IR spectroscopy. $M_{n}=10100 \mathrm{~g} / \mathrm{mol}\left({ }^{1} \mathrm{H}\right.$ NMR). ${ }^{1} \mathrm{H}$ NMR (400 MHz, $\left.\mathrm{CDCl}_{3}\right) \delta$ (ppm): 4.35 ( $\left.\mathrm{C}_{2}-\mathrm{O}-\mathrm{CO}, \mathrm{t}, 2 \mathrm{H}\right), 4.27(\mathrm{CO}-$ $\mathrm{C}$ (Cl) $\left.-\mathrm{CH}_{2}-\mathrm{CH}_{2}-\mathrm{CH}_{2}-\mathrm{CH}_{2}-\mathrm{O}-, \mathrm{t}, 7 \mathrm{H}\right), 4.21$ ( $\mathrm{CO}-\mathrm{CH}(\mathrm{Cl})-\mathrm{CH}_{2}-$ $\left.\mathrm{CH}_{2}-\mathrm{CH}_{2}-\mathrm{CH}_{2}-\mathrm{O}-, \mathrm{t}, 14 \mathrm{H}\right), 4.08\left(\mathrm{CO}-\mathrm{CH}_{2}-\mathrm{CH}_{2}-\mathrm{CH}_{2}-\mathrm{CH}_{2}-\mathrm{CH}_{2}-\right.$ $\mathrm{O}-\mathrm{H}, \mathrm{t}, 7 \mathrm{OH}$ ), 3.66 (O- $\left.\mathrm{CH}_{2}-\mathrm{C}_{2}-\mathrm{O}-, \mathrm{m}, 586 \mathrm{H}\right), 3.40$ ( $\mathrm{C}_{3}-\mathrm{O}-, \mathrm{s}$, $3 \mathrm{H}), 2.33\left(\mathrm{CO}-\mathrm{CH}_{2}-\mathrm{CH}_{2}-\mathrm{CH}_{2}-\mathrm{CH}_{2}-\mathrm{CH}_{2}-\mathrm{O}-\mathrm{H}, \mathrm{t}, 7 \mathrm{OH}\right.$ ), 2.0 (CO$\left.\mathrm{CH}(\mathrm{Cl})-\mathrm{CH}_{2}-\mathrm{CH}_{2}-\mathrm{CH}_{2}-\mathrm{CH}_{2}-\mathrm{O}-, \mathrm{m}, 28 \mathrm{H}\right), 1.76-1.32\left(\mathrm{CO}-\mathrm{CH}_{2}-\right.$ $\mathrm{CH}_{2}-\mathrm{CH}_{2}-\mathrm{C}_{2}-\mathrm{CH}_{2}-\mathrm{O}-$ and, $\mathrm{CO}-\mathrm{CH}(\mathrm{Cl})-\mathrm{CH}_{2}-\mathrm{C}_{2}-\mathrm{CH}_{2}-\mathrm{CH}_{2}-\mathrm{O}-$, $\mathrm{m}, 248 \mathrm{H}) .{ }^{13} \mathrm{C}$ NMR $\left(101 \mathrm{MHz}, \mathrm{CDCl}_{3}\right) \delta$ (ppm): 173.52, 70.57, 64.14, 57.04, 34.11, 28.35, 25.53, 24.57, 22.42. SEC $\left(\mathrm{CHCl}_{3}\right.$, PS calibration): $M_{n}=13500 \mathrm{~g} / \mathrm{mol}, \bigoplus=1.09 . \mathrm{IR}: \mathrm{V} \max / \mathrm{cm}^{-1} 735$, $841,958,1103,1148,1239,1278,1341,1466,1731,1954$, 2885.

\section{Synthesis of mPEG- $b$-poly $\left(\varepsilon \mathrm{CL}-c o-\alpha \mathrm{N}_{3} \varepsilon \mathrm{CL}\right)$}

The azide bearing amphiphilic block copolymer based on $\mathrm{MPEG}$ $b$-poly $\left(\varepsilon \mathrm{CL}-c o-\alpha \mathrm{N}_{3} \varepsilon \mathrm{CL}\right)$ was obtained via the substitution of chloro atoms of mPEG- $b$-poly $(\varepsilon \mathrm{CL}-c o-\alpha \mathrm{Cl} \varepsilon \mathrm{CL})$ by azide groups. An amount (500 mg, $0.05 \mathrm{mmol}$ approximately) of mPEG- $b$ poly $(\varepsilon \mathrm{CL}-c o-\alpha \mathrm{Cl} \varepsilon \mathrm{CL})$ was dissolved in $5 \mathrm{~mL}$ of DMSO. Afterwards, sodium azide ( $34 \mathrm{mg}, 150 \mathrm{~mol} \%$ vs. chloro atoms) was introduced and the reaction mixture was stirred at room temperature for 24 hours. The reaction mixture was diluted with a small amount of $\mathrm{CH}_{2} \mathrm{Cl}_{2}$ and copolymer was recovered by precipitation in anhydrous diethyl ether. The resulting copolymer was dissolved in toluene, and was subsequently centrifuged (4000 rpm, $10 \mathrm{~min}, \mathrm{RT}$ ) to remove insoluble salts. Finally, the azide bearing copolymer was precipitated in anhydrous diethyl ether, filtered and was dried in vacuum and characterized by NMR and FT-IR. $M_{n}=10145 \mathrm{~g} / \mathrm{mol}$ ( ${ }^{1} \mathrm{H}$ NMR). ${ }^{1} \mathrm{H} \mathrm{NMR}\left(400 \mathrm{MHz}, \mathrm{CDCl}_{3}\right) \delta$ (ppm): $4.35\left(\mathrm{C}_{2}-\mathrm{O}-\mathrm{CO}, \mathrm{t}, 2 \mathrm{H}\right), 4.23$ ( $\left.\mathrm{CO}-\mathrm{CH}\left(\mathrm{N}_{3}\right)-\mathrm{CH}_{2}-\mathrm{CH}_{2}-\mathrm{CH}_{2}-\mathrm{CH}_{2}-\mathrm{O}-, \mathrm{t}, 14 \mathrm{H}\right), 4.08\left(\mathrm{CO}-\mathrm{CH}_{2}-\right.$ $\left.\mathrm{CH}_{2}-\mathrm{CH}_{2}-\mathrm{CH}_{2}-\mathrm{CH}_{2}-\mathrm{O}-\mathrm{H}, \mathrm{t}, 70 \mathrm{H}\right), 3.89$ ( $\mathrm{CO}-\mathrm{CH}\left(\mathrm{N}_{3}\right)-\mathrm{CH}_{2}-\mathrm{CH}_{2}-$ $\left.\mathrm{CH}_{2}-\mathrm{CH}_{2}-\mathrm{O}-, \mathrm{t}, 7 \mathrm{H}\right), 3.66$ (O- $\left.\mathrm{CH}_{2}-\mathrm{C}_{2}-\mathrm{O}-, \mathrm{m}, 586 \mathrm{H}\right), 3.40\left(\mathrm{CH}_{3}-\right.$ $\mathrm{O}-, \mathrm{s}, 3 \mathrm{H}), 2.33$ ( $\left.\mathrm{CO}-\mathrm{CH}_{2}-\mathrm{CH}_{2}-\mathrm{CH}_{2}-\mathrm{CH}_{2}-\mathrm{CH}_{2}-\mathrm{O}-\mathrm{H}, \mathrm{t}, 70 \mathrm{H}\right), 1.93-$ $1.34\left(\mathrm{CO}-\mathrm{CH}\left(\mathrm{N}_{3}\right)-\mathrm{C}_{2}-\mathrm{C}_{2}-\mathrm{C}_{2}-\mathrm{CH}_{2}-\mathrm{O}-\right.$, and, $\mathrm{CO}-\mathrm{CH}_{2}-\mathrm{C}_{2}-$ $\left.\mathrm{C}_{2}-\mathrm{C}_{2}-\mathrm{CH}_{2}-\mathrm{O}-\mathrm{H}, \mathrm{m}, 266 \mathrm{H}\right) .{ }^{13} \mathrm{C} \mathrm{NMR}\left(101 \mathrm{MHz}, \mathrm{CDCl}_{3}\right) \delta$ (ppm): 173.52, 70.57, 64.15, 61.90, 34.13, 28.36, 25.54, 24.58 22.29. IR: $v \max / \mathrm{cm}^{-1}: 735,841,958,1103,1148,1239,1278$, 1341, 1466, 1731, 1954, 2106, 2885.

\section{Synthesis of mPEG-PCL}

A diblock copolymer based on methoxypoly(ethyleneglycol)- $b$ poly ( $\varepsilon$-caprolactone) (mPEG-PCL) was synthesised as a control MethoxyPEG (mPEG, $1 \mathrm{~g} 0.2 \mathrm{mmol}$ ) was dissolved in anhydrous toluene and dried by azeotropic distillations ( 3 times) in a glass reactor. Afterwards, $\varepsilon \mathrm{CL}\left(1.06 \mathrm{~g}, 9.2 \mathrm{mmol}\right.$, dried over $\mathrm{CaH}_{2}$ and distilled under reduced pressure prior to use) was introduced via a rubber septum using a glass syringe and the mixture was heated to $50{ }^{\circ} \mathrm{C}$ and stirred for 15 minutes, until a homogeneous mixture was obtained. SnOct $_{2}$ ( $38 \mathrm{mg}, 0.093 \mathrm{mmol}$, dissolved in $\mathrm{CH}_{2} \mathrm{Cl}_{2}$ ) was introduced (under nitrogen) and the reaction was stirred at $100{ }^{\circ} \mathrm{C}$ for 24 hours. The resultant copolymer was dissolved in $5 \mathrm{~mL} \mathrm{CH} \mathrm{Cl}_{2}$ and was precipitated in anhydrous diethyl ether. The synthesized copolymer was dried in vacuo and characterized by ${ }^{1} \mathrm{H}$ NMR and SEC. $M_{n}=10586 \mathrm{~g} / \mathrm{mol}\left({ }^{1} \mathrm{H}\right.$ NMR). ${ }^{1} \mathrm{H}$ NMR (400 MHz, $\left.\mathrm{CDCl}_{3}\right) \delta$ (ppm): 4.23 ( $\mathrm{C}_{2}-\mathrm{O}-\mathrm{CO}, \mathrm{t}$, $2 \mathrm{H}), 4.07\left(\mathrm{CO}-\mathrm{CH}_{2}-\mathrm{CH}_{2}-\mathrm{CH}_{2}-\mathrm{CH}_{2}-\mathrm{CH}_{2}-\mathrm{O}-\mathrm{H}, \mathrm{t}, 98 \mathrm{H}\right), 3.66$ (O$\left.\mathrm{C}_{2}-\mathrm{C}_{2}-\mathrm{O}-, \mathrm{m}, 528 \mathrm{H}\right), 3.40\left(\mathrm{C}_{3}-\mathrm{O}-, \mathrm{s}, 3 \mathrm{H}\right), 2.33\left(\mathrm{CO}-\mathrm{C}_{2}-\right.$ $\left.\mathrm{CH}_{2}-\mathrm{CH}_{2}-\mathrm{CH}_{2}-\mathrm{CH}_{2}-\mathrm{O}-\mathrm{H}, \mathrm{t}, 100 \mathrm{H}\right), 1.70-1.62\left(\mathrm{CO}-\mathrm{CH}_{2}-\mathrm{CH}_{2}-\right.$ $\left.\mathrm{CH}_{2}-\mathrm{C}_{2}-\mathrm{CH}_{2}-\mathrm{O}-\mathrm{H}, \mathrm{m}, 2 \mathrm{2O} \mathrm{H}\right), 1.43-1.37$ ( $\mathrm{CO}-\mathrm{CH}_{2}-\mathrm{CH}_{2}-\mathrm{C}_{2}-$ $\left.\mathrm{CH}_{2}-\mathrm{CH}_{2}-\mathrm{O}-\mathrm{H}, \mathrm{m}, 102 \mathrm{H}\right)$. SEC $\left(\mathrm{CHCl}_{3}\right.$, PS calibration): $M_{n}=$ $12803 \mathrm{~g} / \mathrm{mol}, \oplus=1.07$.

\section{Synthesis of bis-alkyne ethyl disulfide crosslinker}

Anhydrous $\mathrm{CH}_{2} \mathrm{Cl}_{2}\left(40 \mathrm{~mL}\right.$ ) was cooled to $0{ }^{\circ} \mathrm{C}$ in a clean dry round bottom flask using an ice bath. The solvent was purged with nitrogen gas and $1.31 \mathrm{~g}(8.49 \mathrm{mmol})$ 2-hydroxyethyl disulfide, $3.90 \mathrm{~g}$ (20.34 mmol) N-(3-dimethylaminopropyl)- $\mathrm{N}^{\prime}$ ethylcarbodiimide hydrochloride (EDAC), and 4-pentynoic acid $(2 \mathrm{~g}, 20.38 \mathrm{mmol})$ were introduced into the system. $0.25 \mathrm{~g}$ (2.05 mmol) 4-(dimethylamino)pyridine was dissolved in a small amount of dry $\mathrm{CH}_{2} \mathrm{Cl}_{2}$ and was subsequently introduced into the reaction mixture drop wise under magnetic stirring. The reaction contents were stirred for 48 hours at room temperature. Afterwards, the organic phase was washed with 3 x $100 \mathrm{~mL}$ of $1 \mathrm{M}$ hydrochloric acid solution, $3 \times 100 \mathrm{~mL}$ of $1 \mathrm{M}$ sodium hydroxide solution, and $200 \mathrm{~mL}$ of $1 \mathrm{M} \mathrm{NaCl}$ solution. The water residues in the organic phase were removed with anhydrous $\mathrm{MgSO}_{4}$. After filtration, the solvent was removed under reduced pressure to obtain a transparent viscous liquid. The final product was purified by silica gel column chromatography (hexane: ethyl acetate $4: 3, R_{f} 0.36,75 \%$ yield), and characterized by ${ }^{1} \mathrm{H}$ NMR, and ${ }^{13} \mathrm{C} \mathrm{NMR} .{ }^{1} \mathrm{H}$ NMR $(400 \mathrm{MHz}$, $\left.\mathrm{CDCl}_{3}\right) \delta(\mathrm{ppm}): \quad 4.39(\mathrm{t}, 4 \mathrm{H}), 2.95(\mathrm{t}, 4 \mathrm{H}), 2.63-2.57(\mathrm{~m}, 4 \mathrm{H})$, $2.56-2.50(\mathrm{~m}, 4 \mathrm{H}), 2.01(\mathrm{t}, 2 \mathrm{H}) .{ }^{13} \mathrm{C}$ NMR $\left(100 \mathrm{MHz}, \mathrm{CDCl}_{3}\right) \delta$ (ppm): 171.49, 82.31, 69.18, 62.48, 37.19, 33.22, 14.33

\section{Preparation of empty and drug/dye loaded un-crosslinked micelles}

Empty un-crosslinked micelles of mPEG- $b$-poly $\left(\varepsilon C L-c o-\alpha N_{3} \varepsilon C L\right)$ and $\mathrm{MPEG}-\mathrm{PCL}$ diblock copolymer were prepared by a dialysis method using DMSO as an organic solvent. A sample $(50 \mathrm{mg}$ ) of copolymer was dissolved in $5 \mathrm{~mL}$ DMSO and was introduced into Milli-Q water $(20 \mathrm{~mL})$ under vigorous stirring, using a syringe pump with a flow rate of $0.20 \mathrm{~mL} / \mathrm{min}$. The solution was stirred for 2 hours at room temperature and micelles were purified by dialysis overnight against $1 \mathrm{~L}$ of Milli- $\mathrm{Q}$ water using a cellulose dialysis membrane (Spectrapor, cut-off 3500) to remove the DMSO. Drug/dye loaded micelles were prepared in a similar procedure in which $4 \mathrm{mg}$ methotrexate (MTX) or Oregon-green dye and $50 \mathrm{mg}$ copolymer was dissolved in $5 \mathrm{~mL}$ DMSO. The micellar solution was filtered through a membrane syringe filter (pore size: $0.22 \mu \mathrm{m}$ ) (Millex-LG, Millipore Co., USA) before further characterisation.

\section{Preparation of empty and drug/dye loaded core-crosslinked micelles}

For the preparation of crosslinked micelles, $50 \mathrm{mg}(0.005 \mathrm{mmol})$ of mPEG-b-poly( $\left.\varepsilon \mathrm{CL}-c o-\alpha \mathrm{N}_{3} \varepsilon \mathrm{CL}\right)$ copolymer and $12 \mathrm{mg}(0.038$ $\mathrm{mmol}$ ) of bis-alkyne-ethyl disulfide crosslinker were 
A

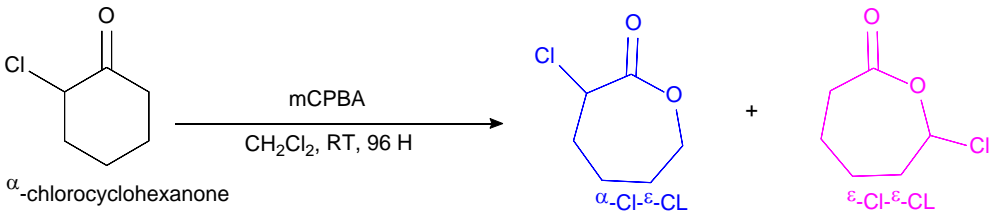

B

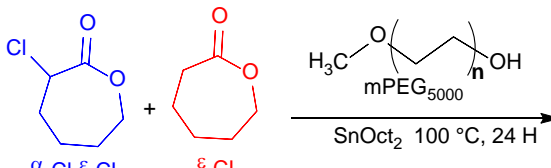<smiles>COCCOCCOC(=O)C(Cl)CCCCCC(=O)OCCCCCCON</smiles>

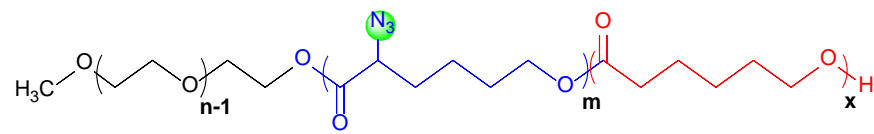
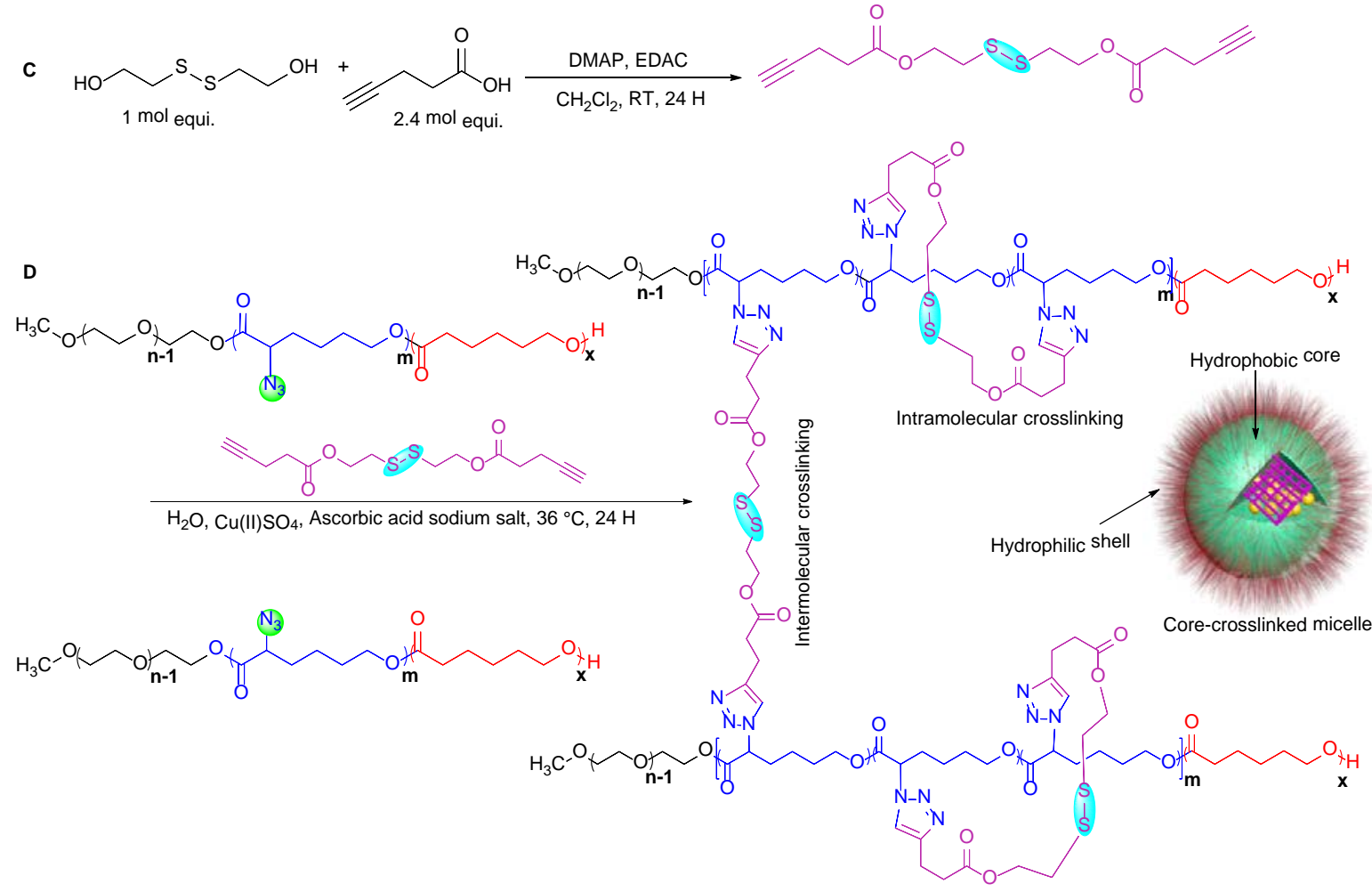

Scheme 2 Schematic representation for the synthesis of functional block copolymers and development of redox-responsive micelles. (A) Functional monomer ( $\alpha \mathrm{Cl} \varepsilon \mathrm{CL}$ ) (B) Ring opening polymerization to synthesize mPEG-b-poly $(\varepsilon C L-c o-\alpha C l \varepsilon C L)$ and subsequent nucleophilic substitution reaction to obtain $\mathrm{mPEG}-b-$ poly $\left(\varepsilon C L-c o-\alpha \mathrm{N}_{3} \varepsilon \mathrm{CL}\right.$,

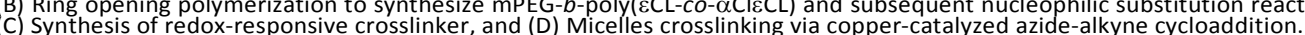

dissolved in DMSO. Afterwards, under vigorous stirring, this mixture was introduced dropwise into $20 \mathrm{~mL}$ Milli-Q water, using a syringe pump with a flow rate of $0.20 \mathrm{~mL} / \mathrm{min}$. The micellar solution was stirred for 2 hours at room temperature. Copper(II) sulfate $(0.20 \mathrm{~mol}$ equivalent to azide groups) and sodium ascorbate $(0.20 \mathrm{~mol}$ equivalent to azide groups) were then introduced into the system. The crosslinking reaction was carried out at $36{ }^{\circ} \mathrm{C}$ for 24 hours. Finally, EDTA ( 2 mol equiv. vs. $\mathrm{Cu}$ ) was introduced into the system and the crosslinked micelles were dialyzed overnight against $1 \mathrm{~L}$ of deionized water. Drug/dye loaded core-crosslinked micelles were prepared in a similar method in which $4 \mathrm{mg}$ methotrexate (MTX) or Oregongreen dye and $50 \mathrm{mg}$ copolymer were dissolved in $5 \mathrm{~mL}$ DMSO in presence of crosslinker.

\section{Determination of drug contents and encapsulation efficiency}

Drug contents and encapsulation efficiencies were determined by dissolving a known amount $(5 \mathrm{mg})$ of freeze dried MTX- 
loaded un-crosslinked or MTX-loaded core-crosslinked micelles in DMSO. The quantification of methotrexate was performed using UV-Vis spectrophotometry (monitoring at $\lambda \max =304$ $\mathrm{nm}$ ). The amount of loaded drug was calculated using a standard curve of MTX in DMSO. Drug content (wt. \%) and encapsulation efficiency (wt. \%) were calculated according to the following equations:

$$
\text { Drug content }(w t . \%)=\frac{\text { (weight of MTX in micelles) }}{\text { (weight of copolymer used) }} \times 100
$$

$$
\mathrm{EE} \%=\frac{\text { (weight of MTX in micelles) }}{\text { (weight of MTX in feed) }} \times 100
$$

\section{Drug release analysis}

The in vitro drug release studies of MTX-loaded un-crosslinked and MTX-loaded core-crosslinked micelles were carried out in non-reducing (PBS, $\mathrm{pH} 7.4$ ) and reducing (10 mmol DTT in PBS) media. $5 \mathrm{mg}$ of freeze dried MTX-loaded un-crosslinked or corecrosslinked micelles were re-dispersed in $2 \mathrm{~mL} \mathrm{PBS} \mathrm{(pH} \mathrm{7.4)} \mathrm{and}$ the solution was placed in a dialysis device (Slide-A-Lyzer ${ }^{\mathrm{TM}}$ mini dialysis device, 3.5K MWCO, Thermo Scientific). The micellar solution was dialysed against $45 \mathrm{~mL}$ of release media at $37^{\circ} \mathrm{C}$ and samples $(1 \mathrm{~mL})$ were taken at appropriate time points and replaced with $1 \mathrm{~mL}$ fresh medium. The collected samples were freeze dried and dissolved in DMSO. The amount of MTX was calculated using UV-Vis spectrophotometry $(\lambda \max =304 \mathrm{~nm})$ via a standard calibration curve of MTX in DMSO.

\section{Cellular uptake analysis using confocal microscopy}

Human breast cancer cells (MCF7) were cultured in Dulbecco's Modified Eagle Medium (DMEM) containing $10 \%$ fetal bovine serum (FBS) and $1 \%$ L-glutamine at $37{ }^{\circ} \mathrm{C}$ with $5 \% \mathrm{CO}_{2}$. For cellular uptake studies, MCF7 cells $\left(3 \times 10^{4}\right.$ cells/well) were seeded on a collagen coated cover glass in a 6 -well plate for 24 hours. Cell culture medium was removed and cells were then treated with the fresh medium containing Oregon-green loaded un-crosslinked or Oregon-green loaded core-crosslinked micelles (100 $\mathrm{\mu g} / \mathrm{mL}$ each) and incubated for 3 hours. Cell culture medium was removed again and cells were washed with PBS (3 times). To label cell membranes, cells were incubated with CellMask ${ }^{\mathrm{TM}}$ deep red plasma membrane stain (working solution concentration $1 \mu \mathrm{L} / \mathrm{mL}$ ) for 10 minutes at $37^{\circ} \mathrm{C}$. After washing with PBS (3 times), cells were incubated with Hoechst dye (working solution concentration $1 \mu \mathrm{L} / \mathrm{mL}$ ) for 30 minutes at $37^{\circ} \mathrm{C}$ to label cell nuclei. After removing the labelling solution, cells were washed with PBS and were fixed with $4 \%$ paraformaldehyde for $15 \mathrm{~min}$ at room temperature. After fixation, cells were washed with PBS and cover glasses were mounted on glass microscope slides using fluorescence mounting medium. The uptake of Oregon-green loaded uncrosslinked or Oregon-green loaded core-crosslinked micelles was examined using a Zeiss 510 Meta confocal microscope.

\section{Cellular uptake analysis using flow cytometry}

For cellular uptake studies by flow cytometry, MCF7 cells were seeded on a 12-well plate at a density of $7.5 \times 10^{4}$ cells/well in $1 \mathrm{~mL}$ of Dulbecco's Modified Eagle Medium (DMEM) containing $10 \%$ fetal bovine serum (FBS) and $1 \%$ L-glutamine for 24 hours $\left(37^{\circ} \mathrm{C}, 5 \% \mathrm{CO}_{2}\right)$. Cell culture medium was removed and was replaced with fresh medium containing Oregon-green loaded un-crosslinked or Oregon-green loaded core-crosslinked micelles (100 $\mathrm{\mu g} / \mathrm{mL}$ each) and incubated for 3 hours. Cell culture medium was removed again and cells were washed with PBS ( 3 times). Cells were then incubated with $100 \mu \mathrm{L}$ of $1 \times$ trypsin/EDTA solution for 3 minutes $\left(37^{\circ} \mathrm{C}\right.$ and $5 \% \mathrm{CO}_{2}$ ). PBS $(0.9 \mathrm{~mL})$ was then added into each well and cells were collected in labelled FACS tubes and were then centrifuged at 1200 RPM for 5 minutes. Supernatant was removed and cells were resuspended in $500 \mu \mathrm{L}$ PBS and analysed using a Beckman Coulter FC 500 flow cytometer equipped with 488 and $633 \mathrm{~nm}$ co-linear lasers. The untreated cells (without micelles) were used as a negative control and data were analysed using Kaluza 1.3 software.

\section{In vitro metabolic activity analysis}

The effects of empty un-crosslinked and core-crosslinked micelles, MTX-loaded un-crosslinked and MTX-loaded corecrosslinked micelles on the metabolic activities of MCF-7 cells were analysed using MTT assays. MCF7 cells were seeded on a 96-well plate at a density of $5 \times 10^{3}$ cells per well in $200 \mu \mathrm{L}$ of Dulbecco's Modified Eagle Medium (DMEM) containing $10 \%$ fetal bovine serum (FBS) and $1 \%$ L-glutamine at $37{ }^{\circ} \mathrm{C}$ with $5 \%$ $\mathrm{CO}_{2}$ for 24 hours. Cell culture medium was removed and replaced with fresh medium containing various concentrations of empty un-crosslinked or empty core-crosslinked micelles, MTX-loaded un-crosslinked, and MTX-loaded core-crosslinked micelles ranging from 100, 250, 500, 750, and $1000 \mu \mathrm{g} / \mathrm{mL}$. Cells were incubated for 48 hours and then $50 \mu \mathrm{L}$ MTT solution (4 $\mathrm{mg} / \mathrm{mL}$ ) was added into each well. Cells were incubated for another 4 hours and medium containing MTT solution was removed and replenished by $150 \mu \mathrm{L}$ DMSO to dissolve any resulting formazan purple crystals.

The optical densities at $570 \mathrm{~nm}$ were measured using a BioTek microplate reader (Synergy 2 Multi-Mode Reader) at a wavelength of $570 \mathrm{~nm}$. The MTT assay was also repeated with a calculated amount of MTX-loaded un-crosslinked or corecrosslinked micelles equivalent to 4.6, $11.523,36$, and 50 $\mu \mathrm{g} / \mathrm{mL}$ of MTX, and also with the same amount of free-MTX as a positive control. The percentage of cellular metabolic activity was calculated using untreated cells (without micelles) as a negative control (100\% metabolic activity).

\section{Apoptosis detection-Hoechst/PI assay}

MCF7 cells were seeded on a 24-well plate at a density of $2 \times$ $10^{4}$ cells per well in DMEM containing $10 \%$ FBS and $1 \%$ Lglutamine at $37{ }^{\circ} \mathrm{C}$ with $5 \% \mathrm{CO}_{2}$ for 24 hours. Cell culture medium was removed and replaced with fresh medium containing a calculated amount of MTX-loaded un-crosslinked or core-crosslinked micelles, equivalent to various amounts of $\operatorname{MTX}(4.6,11.523,36$, and $50 \mu \mathrm{g} / \mathrm{mL})$. Cells were incubated for 48 hours and cell culture medium was then removed and cells 
were washed with ice cold PBS. Afterwards, cells were incubated with $1 \mathrm{~mL}$ Hoechst 33342 solution $(10 \mu \mathrm{L} / \mathrm{mL}$ in ice cold PBS) at $37{ }^{\circ} \mathrm{C}$ for 15 minutes. After removing the labelling solution and washing the cells with ice cold PBS, cells were incubated with $1 \mathrm{~mL}$ propidium iodide (PI) solution $(5 \mu \mathrm{L} / \mathrm{mL}$ in ice cold PBS) at room temperature for 15 minutes in dark. The PI labelling solution was removed and cells were washed (3 times) with ice cold PBS and were observed immediately under an inverted-fluorescence microscope (EVOS ${ }^{\mathrm{TM}} \mathrm{FL}$ Cell Imaging System equipped with a Sony ICX285AQ colour CCD camera). The untreated cells (without micelles) were used as a negative control and cells treated with various amounts of free MTX (4.6, $11.523,36$, and $50 \mu \mathrm{g} / \mathrm{mL}$ ) dissolved in cell culture medium were used as positive controls. Cells were also treated with various amount of MTX dissolved in DMSO-medium as another positive control. A stock solution of MTX was prepared by first dissolving MTX in $200 \mu \mathrm{L}$ DMSO, and volume was made up to 10 $\mathrm{mL}$ with DMEM. This stock solution was further diluted with DMEM to obtain the required concentration of MTX. The percentages of live, apoptotic, and dead cells were calculated using Infinity Analyze software (Infinity Analyze 3R, Lumenera Corporation).

\section{Annexin-V/PI apoptosis assay}

MCF7 cells were seeded on a 24-well plate at a density of $7.5 \times$ $10^{4}$ cells/well in DMEM containing $10 \% \mathrm{FBS}$ and $1 \%$ L-glutamine for 24 hours $\left(37^{\circ} \mathrm{C}, 5 \% \mathrm{CO}_{2}\right)$. Cell culture medium was removed and replaced with fresh medium containing a calculated amount of MTX-loaded un-crosslinked or MTX-loaded corecrosslinked micelles, equivalent to various amounts of MTX (4.6, $11.5,23$, and $50 \mu \mathrm{g} / \mathrm{mL}$ ) and cells were then incubated for 48 hours. After the incubation period, floating cells were collected into labelled FACS tubes on ice $\left(4^{\circ} \mathrm{C}\right)$ and attached cells were trypsinized and pooled together with corresponding floating cells. Samples were centrifuged at $1200 \mathrm{rpm}$ for $5 \mathrm{~min}$ at $4{ }^{\circ} \mathrm{C}$ and supernatants were then discarded and cells were resuspended in $5 \mu \mathrm{L}$ annexin V-FITC along with $100 \mu \mathrm{L} 1 \times$ annexin $\checkmark$ binding buffer. Samples were incubated for $15 \mathrm{~min}$ at room temperature in the dark and were then treated with $10 \mu \mathrm{L} \mathrm{PI} \mathrm{(50}$ $\mu \mathrm{g} / \mathrm{mL}$ in $1 \times$ annexin $\mathrm{V}$ binding buffer) along with an extra 400 $\mu \mathrm{L}$ annexin $\mathrm{V}$ binding buffer and were incubated in the dark at 4 ${ }^{\circ} \mathrm{C}$ for $10 \mathrm{~min}$. Samples were analysed using a Beckman Coulter FC-500 flow cytometer and data were analysed using Kaluza 1.3 software.

\section{Statistical analysis}

All experiments were performed at least three times and data are expressed as mean \pm standard deviation. The significance of the results was evaluated by Student's t-test. The difference between two groups was considered statistically significant for $p<0.05$, and very significant for $p<0.01$.

\section{Results}

Synthesis and characterisation of block copolymers
To obtain a functional amphiphilic block copolymer, we first synthesized a functional lactone (i.e. $\alpha$-chloro- $\varepsilon$-caprolactone) from the oxidation of 2-chlorocyclohexanone by 3chloroperoxybenzoic acid ( $m$ CPBA) as shown in Scheme 2A. The crystals of unreacted $\mathrm{mCPBA}$ and its reduced form (m-chloro benzoic acid) were removed by filtration, whereas, the remaining residues of both acids in the product mixture were quenched and removed by extraction with saturated solutions of sodium thiosulfate and sodium bicarbonate. The oxidation of 2-chlorocyclohexanone resulted in two isomers i.e. $\alpha \mathrm{Cl} \varepsilon \mathrm{CL}$, and $\varepsilon \mathrm{Cl} \varepsilon \mathrm{CL}$, in a $95 / 5$ molar ratio. In this work, the $\alpha \mathrm{Cl} \varepsilon \mathrm{CL}$ was purified by silica gel column chromatography with high yield (70 $\%)$ and high purity, as also revealed by ${ }^{1} \mathrm{H}$ NMR spectroscopy (Fig. 1A). The appearance of chemical shifts at 4.69 and 4.29 ppm in ${ }^{1} \mathrm{H}$ NMR spectrum, confirmed the formation of the functional lactone.

The functional copolymer based on MPEG- $b$-poly $(\varepsilon \mathrm{CL}-c o$ $\alpha \mathrm{Cl} \varepsilon \mathrm{CL}$ ) was obtained by the ring-opening polymerization of $\alpha \mathrm{Cl} \varepsilon \mathrm{CL}$ and $\varepsilon \mathrm{CL}$. The PEG bearing one $\mathrm{OH}$ functional group at the $\omega$-chain end was used as an initiator, whereas tin octoate was used as a catalyst as shown in Scheme $2 \mathrm{~B}$. The polymerization was performed in bulk (without solvent) at $100{ }^{\circ} \mathrm{C}$. The disappearance of monomer signals in ${ }^{1} \mathrm{H}$ NMR spectrum revealed quantitative conversion of both monomers after 24 hours. The block copolymer was purified by precipitation in diethyl ether from a solution in $\mathrm{CH}_{2} \mathrm{Cl}_{2}$ to remove catalyst residues. The ${ }^{1} \mathrm{H}$ NMR spectrum of mPEG- $b$-poly $(\varepsilon \mathrm{CL}-c o-\alpha \mathrm{Cl} \varepsilon \mathrm{CL})$ is shown in Fig. 1B. The molar mass of mPEG- $b$-poly $(\varepsilon \mathrm{CL}-c o-$ $\alpha \mathrm{Cl} \varepsilon \mathrm{CL}$ ) copolymer was calculated by the comparison of the relative intensity of the proton of $\mathrm{PCL}$ at $2.33 \mathrm{ppm}\left(\mathrm{C}_{2}-\mathrm{C}(\mathrm{O})\right.$, peak " $\mathrm{k}$ ", in Fig. 1B) and relative intensity of the proton of poly $(\alpha \mathrm{Cl} \varepsilon \mathrm{CL})$ at $4.21 \mathrm{ppm}\left(\mathrm{CO}-\mathrm{CH}(\mathrm{Cl})-\mathrm{CH}_{2}-\mathrm{CH}_{2}-\mathrm{CH}_{2}-\mathrm{C}_{2}-\mathrm{O}-\right.$, peak " $\mathrm{j}$ ", in Fig. 1B) with the methoxy end group of the mPEG (3.3 ppm, peak "a" in Fig. 1B). Integration of the ${ }^{1} \mathrm{H} N M R$ spectrum revealed that the molar mass of synthesized block copolymer was $10100 \mathrm{~g} / \mathrm{mol}$ with a degree of polymerization (Dp) of 7 for $\alpha \mathrm{Cl} \varepsilon \mathrm{CL}$ and 35 for $\varepsilon \mathrm{CL}$. The NMR-derived molar mass was in good agreement with the theoretically achievable molar mass based on the co-monomers feed.

The number average molecular weight $\left(M_{n}\right)$ and dispersity $(\boxplus)$ were determined using size exclusion chromatography (SEC). The shift towards lower elution time of MPEG- $b$-poly $(\varepsilon C L-c o-$ $\alpha \mathrm{Cl} \varepsilon \mathrm{CL}$ ) (Fig. S3) as compared to the MPEG was an evidence of increase in molar mass after polymerization. The SEC analysis of $\mathrm{mPEG}-b$-poly $(\varepsilon \mathrm{CL}-c o-\alpha \mathrm{Cl} \varepsilon \mathrm{CL})$ block copolymer showed number average molar mass of $13500 \mathrm{~g} / \mathrm{mol}$ with dispersity of 1.09 .

In a second step, the pendent chloro atoms of copolymer were converted into azides in order to synthesize a 'clickable' block copolymer. The ${ }^{1} \mathrm{H}$ NMR (Fig. 1C) and ${ }^{13} \mathrm{C}$ NMR (Fig. S2) spectra of $\mathrm{mPEG}-b$-poly $\left(\varepsilon \mathrm{CL}-c o-\alpha \mathrm{N}_{3} \varepsilon \mathrm{CL}\right)$ revealed the complete conversion to azides, as also confirmed by FT-IR (Fig. 1D). Specifically, the IR spectrum of mPEG- $b$-poly $\left(\varepsilon C L-c o-\alpha N_{3} \varepsilon C L\right)$ showed the expected absorption of the azide group at $2106 \mathrm{~cm}^{-}$ 1 . 

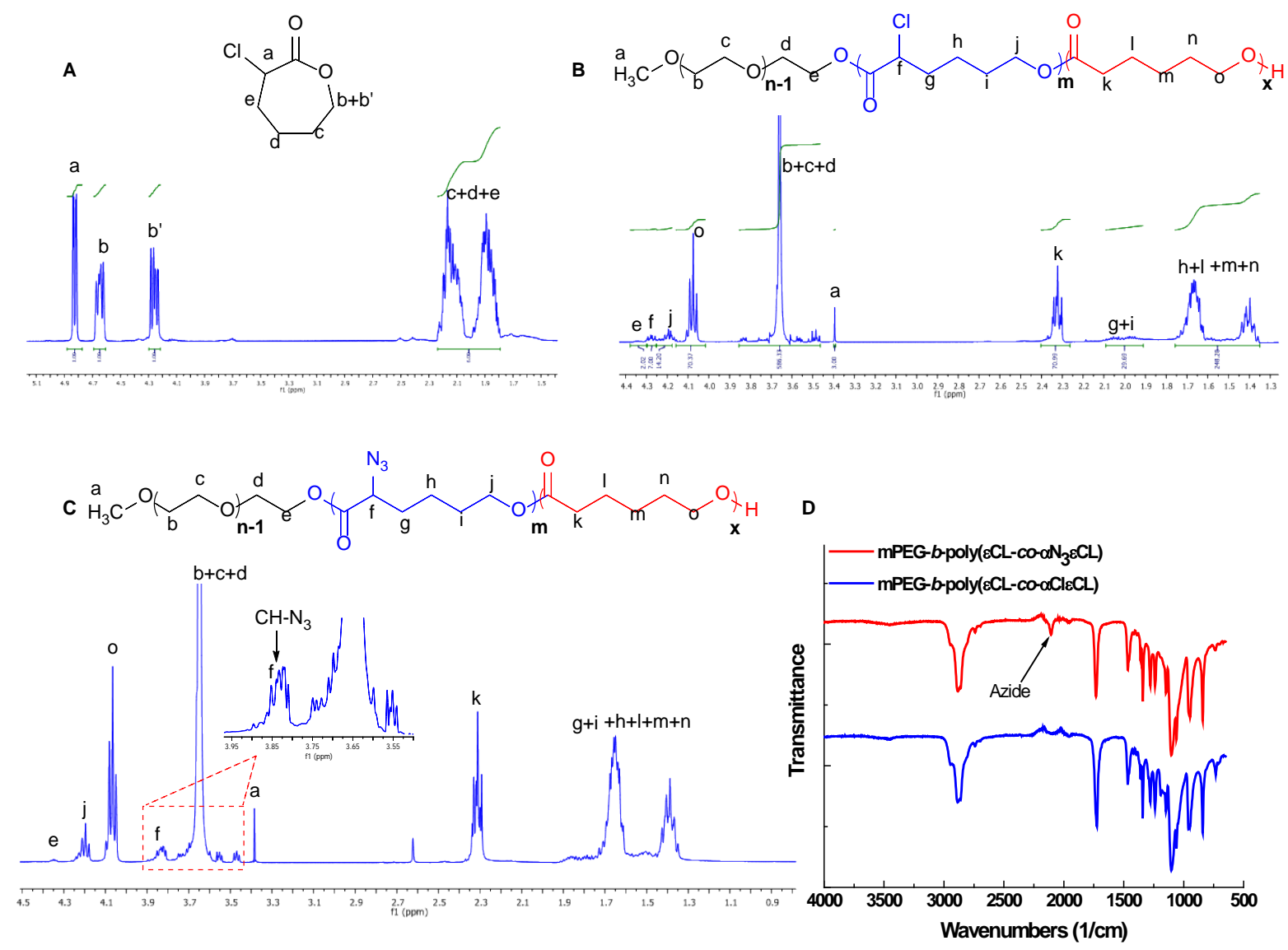

Fig. 1 Characterization of the functional monomer and block copolymers. (A) ${ }^{1} \mathrm{H}$ NMR spectrum of $\alpha \mathrm{Cl} \varepsilon \mathrm{CL}$, (B) ${ }^{1} \mathrm{H}$ NMR spectrum of mPEG- $b$-poly $(\varepsilon C L-c o-\alpha C l \varepsilon C L),(C){ }^{1} \mathrm{H}$ NMR spectrum of mPEG- $b$-poly $\left(\varepsilon C L-c O-\alpha N_{3} \varepsilon C L\right)$, and (D) FTIR spectra of block copolymers before and after azide substitution.

Preparation and characterization of MTX-loaded redox-responsive core-crosslinked micelles

To incorporate reduction sensitive bridges into the core of the micelles, a bis-alkyne-ethyl disulfide crosslinker was synthesized by reacting 4-pentynoic acid with bis(2-hydroxyethyl) disulfide, using EDAC as a carboxylic acid activating agent and DMAP as a catalyst (Scheme $2 \mathrm{C}$ ). The resulting compound was purified by silica gel column chromatography ( $75 \%$ yield). The structure of bis-alkyne-ethyl disulfide crosslinker was confirmed by ${ }^{1} \mathrm{H} N M R$ and ${ }^{13} \mathrm{C}$ NMR (Fig. 2A, and Fig. S5, respectively). The ${ }^{1} \mathrm{H}$ NMR signals at $4.39 \mathrm{ppm}$ and ${ }^{13} \mathrm{C}$ NMR signals at $62.48 \mathrm{ppm}$ confirmed the formation of the crosslinker.

Reactive micelles based on mPEG- $b$-poly $\left(\varepsilon \mathrm{CL}-c o-\alpha \mathrm{N}_{3} \varepsilon \mathrm{CL}\right)$ were then prepared using a dialysis method in which DMSO was used as an organic solvent. Methotrexate was loaded into the hydrophobic cores of the micelles which were subsequently crosslinked by the bis-alkyne ethyl disulfide crosslinker using copper catalyzed azide-alkyne cycloaddition as shown in Scheme 2D. The kinetics of the 'click' reaction were monitored by FT-IR (Fig. 2B). The infrared absorption peak at $2106 \mathrm{~cm}^{-1}$ (characteristic of the azide group) completely disappeared in favour of a new peak at $1660 \mathrm{~cm}^{-1}$ (typical of the triazole ring), as also reported previously, ${ }^{40}$ suggesting essentially complete cross-linking.

The size distributions and morphologies of micelles were analysed using DLS and TEM, respectively. The characterization data of micelles are summarized in Table 1 . The empty micelles were of an average size of $36 \pm 7 \mathrm{~nm}$ as shown by DLS (Fig. 3A, right image) with spherical morphologies as confirmed by TEM (Fig. 3A, left image). These sizes were very similar to those of unsubstituted mPEG-PCL micelles ( $34 \mathrm{~nm}$, Fig S6). By contrast, the average size of MTX-loaded un-crosslinked micelles was 53 $\pm 9 \mathrm{~nm}$ with a summated poly dispersity index $(0.12 \pm 0.05)$ as revealed by DLS (Fig. 3B right image). TEM analysis (Fig. 3B left image) showed the predominantly spherical morphology of MTX-loaded micelles with average sizes of $46 \mathrm{~nm}$ (Fig. 3B middle image). MTX-loaded core-crosslinked micelles were slightly larger ( $67 \pm 12 \mathrm{~nm}$, and $63 \mathrm{~nm}$ ) as determined by DLS (Fig. 3C right image) and TEM (Fig. $3 C$ left image), respectively, as compared with MTX-loaded un- crosslinked micelles.

The zeta potentials of the empty, MTX-loaded un-crosslinked and MTX-loaded core-crosslinked micelles were near to neutral $(-2.81 \pm 0.91,-3.50 \pm 1.25$, and $-2.30 \pm 2.21 \mathrm{mv}$, respectively) as shown in Fig. S8.

Drug contents and encapsulation efficiency of MTX-loaded uncrosslinked and core-crosslinked micelles were determined 

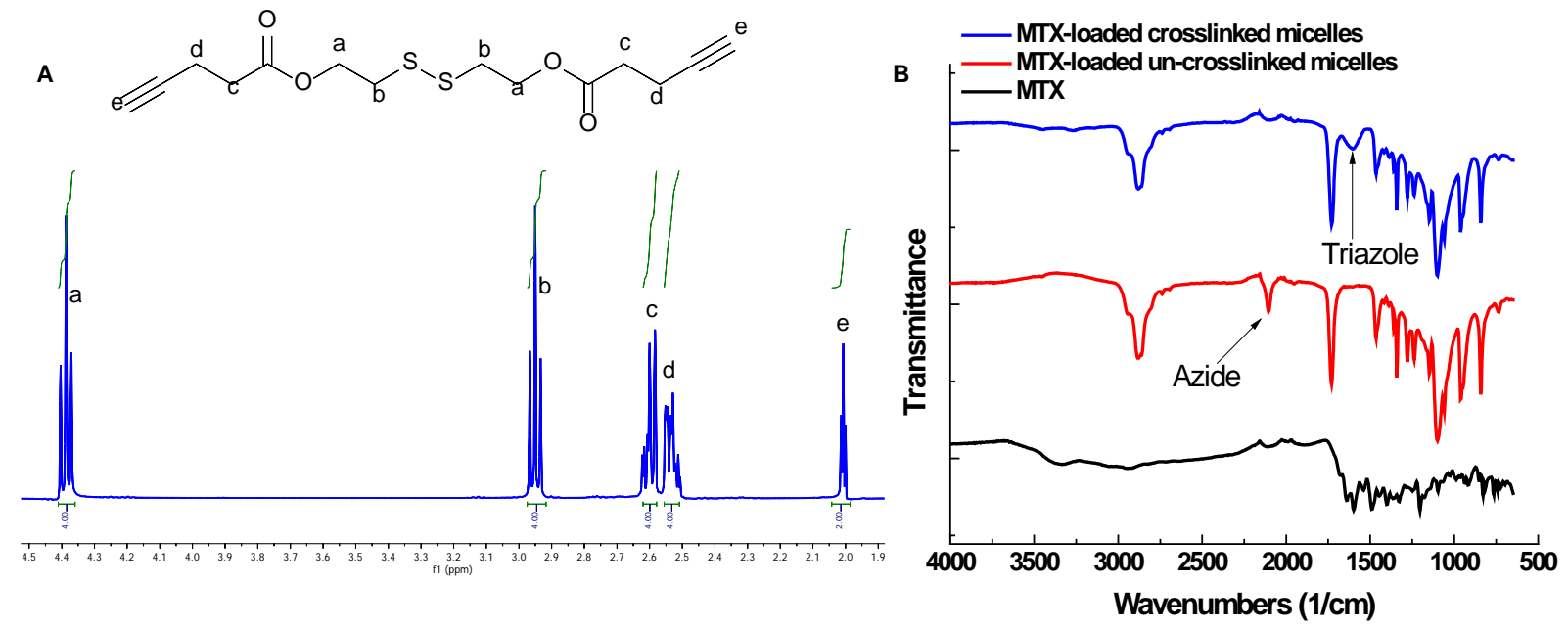

Fig. 2 Characterization of redox-responsive crosslinker and core-crosslinked micelles. (A) ${ }^{1} \mathrm{H}$ NMR spectrum of crosslinker and (B) FTIR spectra of freeze-dried MTXloaded un-crosslinked and core-crosslinked micelles.

using UV-Vis spectrophotometry $(\lambda \max =304 \mathrm{~nm})$ through a standard curve of MTX in DMSO. The core-crosslinked micelles showed significantly higher drug contents $(4.9 \pm 0.6 \mathrm{wt}$. \%) and better encapsulation efficiency $(61.8 \pm 7.4 \%)$ as compared with un-crosslinked micelles $(3.1 \pm 0.4$ wt. \%, and $39.3 \pm 5.2 \%$, respectively), as shown in table 1.

To study the cellular uptake of micelles, Oregon-green loaded un-crosslinked micelles and Oregon-green loaded corecrosslinked micelles were prepared. For this purpose, Oregongreen dye was synthesized by the methanesulfonic acid catalysed reaction of 4-fluroresorcinol with trimellitic anhydride (Scheme. S1). The structure of Oregon-green was confirmed by ${ }^{1} \mathrm{H}$ NMR (Fig. S9) and electrospray ionization mass spectrometry (Fig. S10). The Oregon-green loaded un-crosslinked micelles and Oregon-green loaded core-crosslinked micelles were of mean sizes of 43 and $52 \mathrm{~nm}$, respectively, as revealed by DLS measurements (Fig. S11).

\section{In vitro drug release studies}

Drug release of MTX from the micelles was carried out under reducing and non-reducing conditions at $37{ }^{\circ} \mathrm{C}$. Due to the complexities of the intracellular environment, in which many reducing species may be present at different times, GSH alone was not used in these model studies, ${ }^{19}$ and instead DTT was used as a simple known reductant. The amount of drug release was determined using UV-Vis spectrophotometry monitoring at $304 \mathrm{~nm}$. As shown in Fig. 4, in PBS (pH 7.4), MTX-loaded uncrosslinked micelles showed a burst release of drug during the first 12 hours ( $35 \%$ drug release) followed by a steady and temporal drug release during which $90 \%$ drug was released up to 96 hours. In contrast, core-crosslinked micelles exhibited a reduced burst release of MTX in non-reducing conditions, with $\sim 20 \%$ MTX detected in the dialysate during the first 12 hours. Methotrexate was mostly retained by core-crosslinked micelles in PBS at $37^{\circ} \mathrm{C}$ even up to $96 \mathrm{~h}$, after which time $76 \%$ MTX was still retained in the micelles. However, MTX-loaded corecrosslinked micelles exhibited about $60 \%$ drug release at 12 hours and $89 \%$ drug release at 24 hours under reducing conditions (10 mmol DTT).

\section{In vitro cellular uptake}

In vitro cellular uptake of un-crosslinked and reversibly corecrosslinked micelles was investigated using flow cytometry and confocal laser scanning microscopy. For this purpose, Oregongreen loaded un-crosslinked and core-crosslinked micelles were incubated for 3 hours with human breast cancer (MCF7)

\begin{tabular}{|c|c|c|c|c|c|}
\hline $\begin{array}{l}\text { Micelles type } \\
\text { Mello }\end{array}$ & Size $($ d. $n m) \pm S D$ & $\mathrm{PDI} \pm \mathrm{SD}$ & $\begin{array}{l}\text { Zeta potential } \\
(\mathrm{mv}) \pm S \mathrm{~S}\end{array}$ & $\begin{array}{l}\text { Drug content } \\
(\mathrm{Wt} \%) \pm \mathrm{SD}\end{array}$ & $\begin{array}{c}\text { Encapsulation } \\
\text { efficiency }(\%) \pm \text { SD }\end{array}$ \\
\hline Empty micelles & $36 \pm 7$ & $0.21 \pm 0.02$ & $-2.81 \pm 0.91$ & NA & NA \\
\hline $\begin{array}{l}\text { MTX-loaded } \\
\text { un-crosslinked micelles }\end{array}$ & $53 \pm 9$ & $0.12 \pm 0.05$ & $-3.50 \pm 1.25$ & $3.14 \pm 0.42$ & $39.3 \pm 5.2$ \\
\hline $\begin{array}{l}\text { MTX-loaded core- } \\
\text { crosslinked micelles }\end{array}$ & $67 \pm 12$ & $0.24 \pm 0.03$ & $-2.30 \pm 2.21$ & $4.94 \pm 0.60$ & $61.8 \pm 7.5$ \\
\hline
\end{tabular}


A
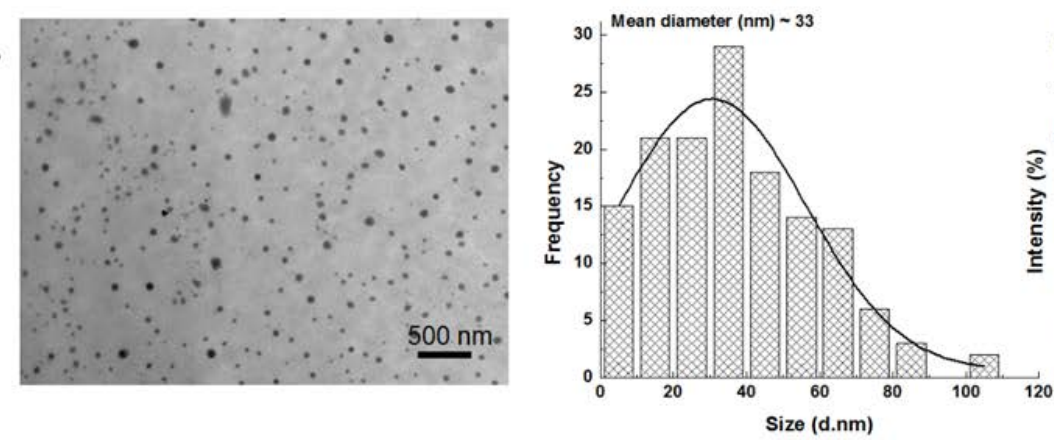

B

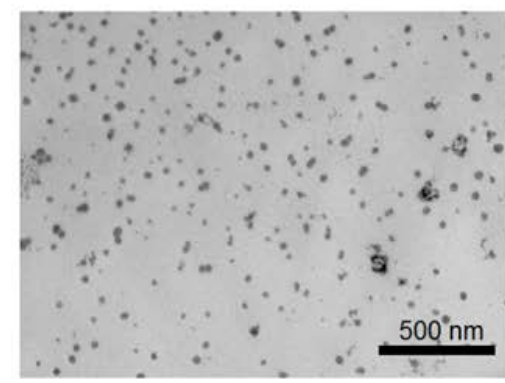

C

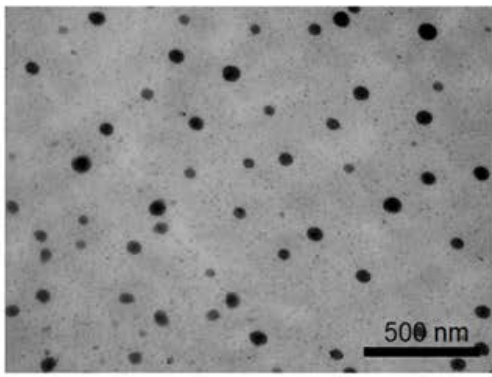

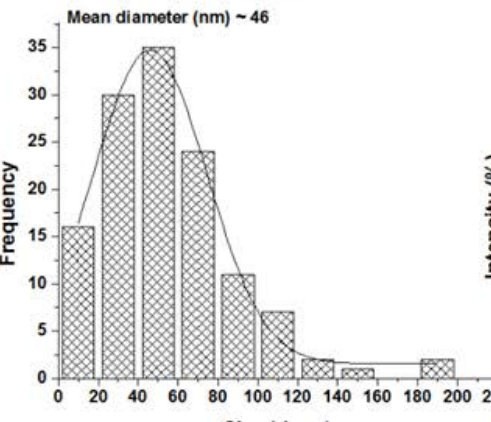

Size (d.nm)

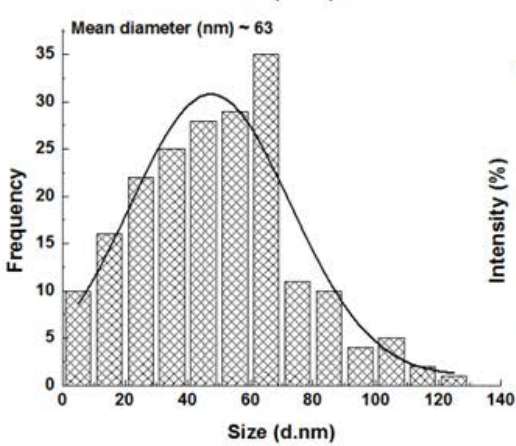

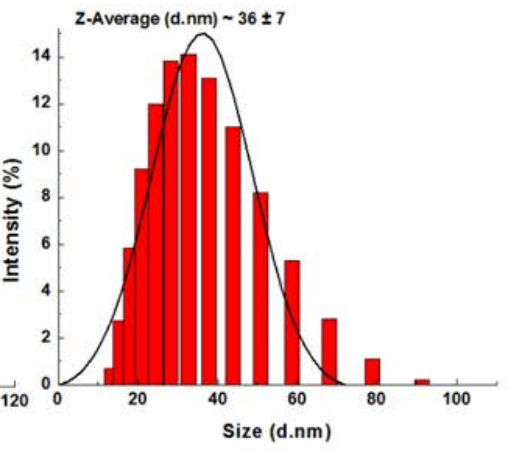
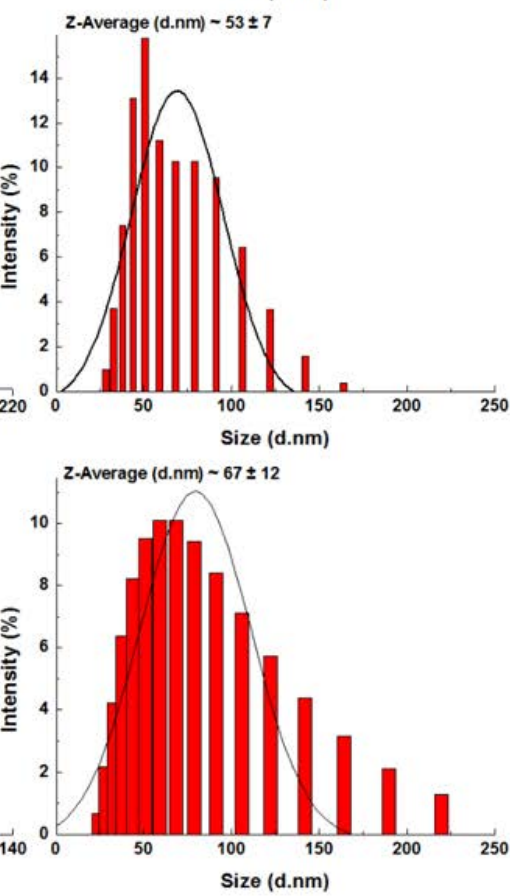

Fig. 3 Size and morphological characterization of micelles. (A) Empty micelles, (B) MTX-loaded un-crosslinked micelles, and (C) MTX-loaded core-crosslinked micelles. Left images showing TEM micrographs, middle images showing size distributions calculated using ImageJ software, and right images represent size distribution measured using dynamic light scattering.

cells. Flow cytometry analysis showed that Oregon-green loaded un- crosslinked and core-crosslinked micelles were efficiently endocytosed by MCF7 cells (Fig. 5A and 5B, respectively). Cells incubated without micelles were used as a negative control to correct the auto fluorescence. The median fluorescence intensities arising from negative control, Oregongreen loaded un-crosslinked and Oregon-green loaded corecrosslinked micelles were 5.23, 62.08, and 63.35 (arbitrary units), respectively. Flow cytometry analysis revealed that the extents of uptake of un-crosslinked and core-crosslinked micelles were 93 and $94 \%$, respectively, showing that crosslinking the micelle-core did not negatively affect cellular entry of micelles.

Confocal laser scanning microscopy was used to analyse the intracellular localization of micelles. MCF7 cells were incubated with Oregon-green loaded un-crosslinked and core-crosslinked micelles for 3 hours. Cell membranes were stained with CellMask $^{\mathrm{TM}}$ deep red plasma membrane stain, whereas cell nuclei were stained with Hoechst dye. Fig. $5 \mathrm{C}$ shows the CLSM images of cellular uptake of Oregon-green loaded un- crosslinked micelles. It is apparent that Oregon-green loaded micelles were internalized by MCF7 cells and were localized mostly in the cytoplasm at the 3-hour time-point.

Interestingly, Oregon-green loaded core-crosslinked micelles were localized both in the cytoplasm and in the nuclei of the MCF7 cells as shown by the green fluorescence in merged CLMS images (Fig. 5D). The observed green fluorescence located in the proximity of cell nuclei was probably due to the localization of core-crosslinked micelles or delivery of dye following endosomal/lysosomal escape. ${ }^{41}$

\section{MTT assay/cytotoxicity studies}

The in vitro effects of the empty mPEG- $b$-poly $\left(\varepsilon \mathrm{CL}-c o-\alpha \mathrm{N}_{3} \varepsilon \mathrm{CL}\right)$ micelles and their crosslinked counter parts were investigated in MCF7 cells using MTT assays. For this purpose, MCF7 cells were treated with various amounts of empty un-crosslinked and crosslinked micelles for 48 hours. The results of MTT assays are depicted in Fig. 6A. The MTT assay results showed more than 90 $\%$ metabolic activity of MCF7 cells treated with 


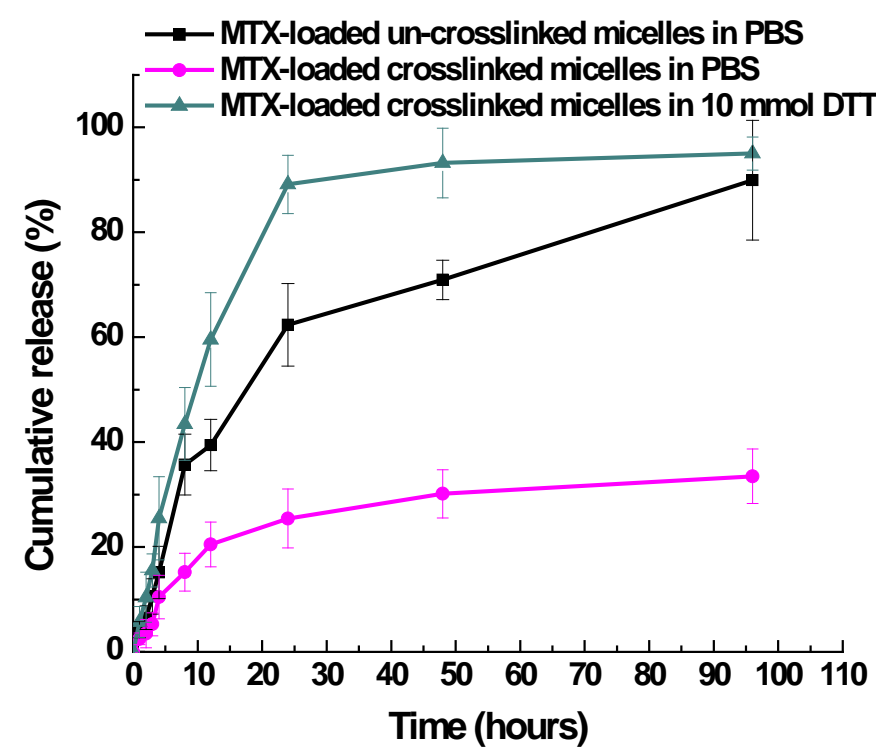

Fig. 4 Analysis of methotrexate (MTX) release from MTX-loaded un-crosslinked and core-crosslinked micelles at $37^{\circ} \mathrm{C}$.

un-crosslinked and core-crosslinked empty micelles up to concentrations of $500 \mu \mathrm{g} / \mathrm{mL}$ as compared with the negative control. At maximum tested concentration of $1000 \mu \mathrm{g} / \mathrm{mL}$, cells treated with un-crosslinked and core-crosslinked micelles showed metabolic activities of $90.8 \pm 2.7$, and $75 \pm 2 \%$, respectively.

In contrast, MTX-loaded un-crosslinked and MTX-loaded corecrosslinked micelles decreased the metabolic activity of MCF7 cells in a dose dependent pattern (Fig. 6A). Specifically, MTXloaded un-crosslinked micelles showed a metabolic activity of $50.8 \pm 4$ and $45.4 \pm 2.5 \%$ at concentrations of 500 and 1000 $\mu \mathrm{g} / \mathrm{mL}$, respectively. Interestingly, MTX-loaded core-crosslinked micelles proved to be significantly more potent as compared to un-crosslinked counterparts. At concentrations of 500 and 1000 $\mu \mathrm{g} / \mathrm{mL}, \mathrm{MTX}$-loaded core-crosslinked micelles decreased the metabolic activity of MCF7 cells to $14 \pm 10.5$, and $8.2 \pm 3.6 \%$, respectively.

Since the drug contents of MTX-loaded un-crosslinked and corecrosslinked micelles were different, therefore, MTT assays were also repeated with calculated amounts of MTX-loaded uncrosslinked or core-crosslinked micelles, equivalent to various amounts of free $\operatorname{MTX}(4.6,11.5,23,36$ and $50 \mu \mathrm{g} / \mathrm{mL})$. The metabolic activities of MCF7 cells as a function of MTX concentrations are shown in Fig. 6B. It was observed that the metabolic activities of MCF7 cells treated with MTX-loaded core-crosslinked micelles, equivalent to $50 \mu \mathrm{g} / \mathrm{mL}$ of MTX, were significantly decreased as compared to the MTX-loaded uncrosslinked micelles and free MTX. These findings indicated that crosslinked micelles enhanced the cytotoxicity of MTX to a greater extent as compared with the free MTX and MTX-loaded un-crosslinked micelles.

\section{Apoptosis inducing potential of MTX-loaded core-crosslinked micelles}

In order to investigate whether the cell death observed in MCF7 cells treated with free MTX and MTX-loaded formulations could be due to apoptosis, Hoechst/PI double staining was performed. The morphological changes in cell nuclei were analysed using a fluorescence microscope. The MCF7 cells incubated with different concentrations of free MTX and MTXloaded formulations showed obvious morphological changes in cell nuclei after treatment for 48 hours, as compared with the control untreated cells. As shown in Fig. S-12, the untreated cells were regular and intact with less bright blue nuclei and without red fluorescence. In contrast, cells treated with MTXloaded un-crosslinked and core-crosslinked micelles (Fig. 7A and 7B, respectively) and free MTX (Fig. S13A) showed characteristic features of apoptosis and cell death.

The percentage of apoptotic and dead cells increased correspondingly in a dose dependent manner after treatment with MTX-loaded formulations. Specifically, MTX-loaded uncrosslinked micelles at $50 \mu \mathrm{g} / \mathrm{mL}$ equivalent of MTX resulted in $20 \pm 1.8$ and $15 \pm 2.3 \%$ apoptotic and dead cells, respectively, as shown in Fig. 7C. The percentage of apoptotic and dead cells also increased after treatment with MTX-loaded corecrosslinked micelles (Fig. 7D) as compared with their uncrosslinked counterparts. In particular, MTX-loaded corecrosslinked micelles at $23 \mu \mathrm{g} / \mathrm{mL}$ equivalent of MTX resulted in approximately $46 \pm 6$ and $33 \pm 5 \%$ apoptotic and dead cells, respectively. When the amount of MTX-loaded core-crosslinked micelles was increased to $50 \mu \mathrm{g} / \mathrm{mL}$ equivalent of $\mathrm{MTX}$, the percentage of dead cells was also increased showing $78 \pm 8 \%$ dead cells and $9 \pm 4 \%$ apoptotic cells. However, MCF7 cells treated with free MTX (Fig. S13B) showed a lower percentage of apoptotic and dead cells as compared with MTX-loaded formulations. At $50 \mu \mathrm{g} / \mathrm{mL}$ free MTX concentration, the percentages of apoptotic and dead cells were $10 \pm 3$ and $8 \pm 2$ $\%$, respectively.

To further confirm that cell death was induced via apoptosis by MTX-loaded formulations, annexin V-FITC/PI assays were performed. The proportion of live, apoptotic, and dead cells stained with annexin V-FITC/PI assay were calculated using flow cytometry. The forward scattering (FS) and side scattering (SS) were integrated to provide information about cell size, and cell morphology, respectively. The proportion of live, apoptotic, and dead cells were calculated by the comparison of fluorescence corresponding to annexin V-FITC (FL1) and fluorescence corresponding to propidium iodide (FL3). The results of annexin $\mathrm{V}$-FITC/PI assays are shown in Fig. 8. The negative control cells (without treatment) appeared to be regular and with low fluorescence (i.e. auto fluorescence) as shown in Fig. S14A. The auto fluorescence generated by control cells was subtracted from the flow cytometry data of treated samples by applying appropriate gating.

The flow cytometry results revealed that MCF7 cells treated with MTX-loaded un-crosslinked micelles exhibited dose dependent increases in the proportions of apoptotic and dead cells (Fig. 8C) as compared to untreated cells (Fig. S14C). The MTX-loaded un-crosslinked micelles at $50 \mu \mathrm{g} / \mathrm{mL}$ equivalent to free MTX gave rise to $23 \pm 4$ and $8 \pm 5 \%$ apoptotic and dead cells, respectively. In contrast with the un-crosslinked micelles, the MTX-loaded core-crosslinked micelles enhanced the 

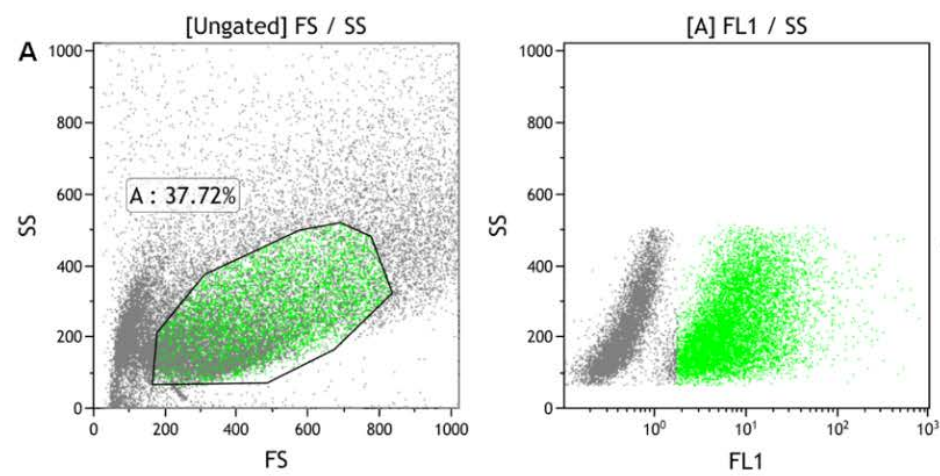

Medium contro

OG-loaded un-crosslinked micelles
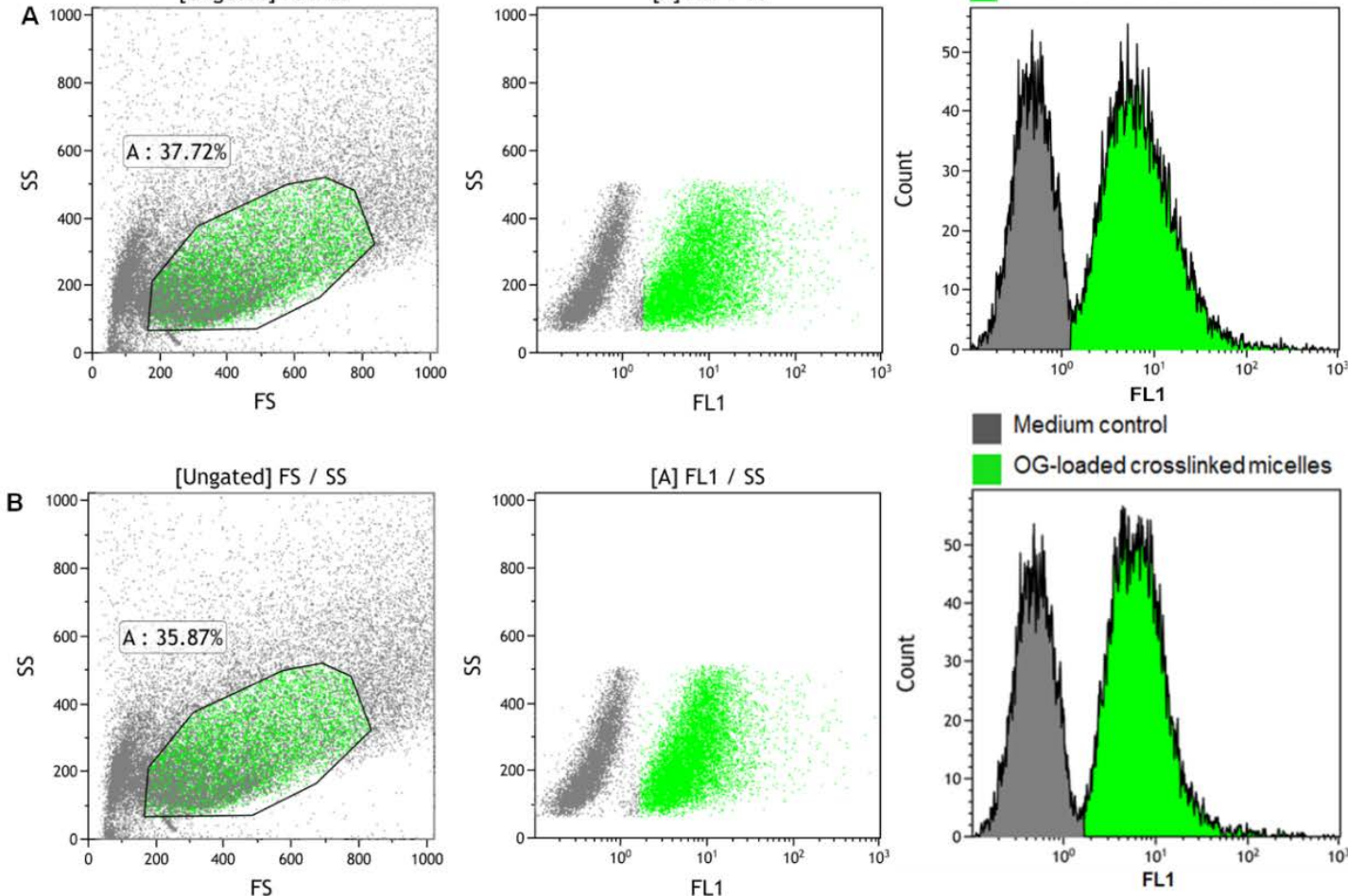

Medium contro

OG-loaded crosslinked micelles
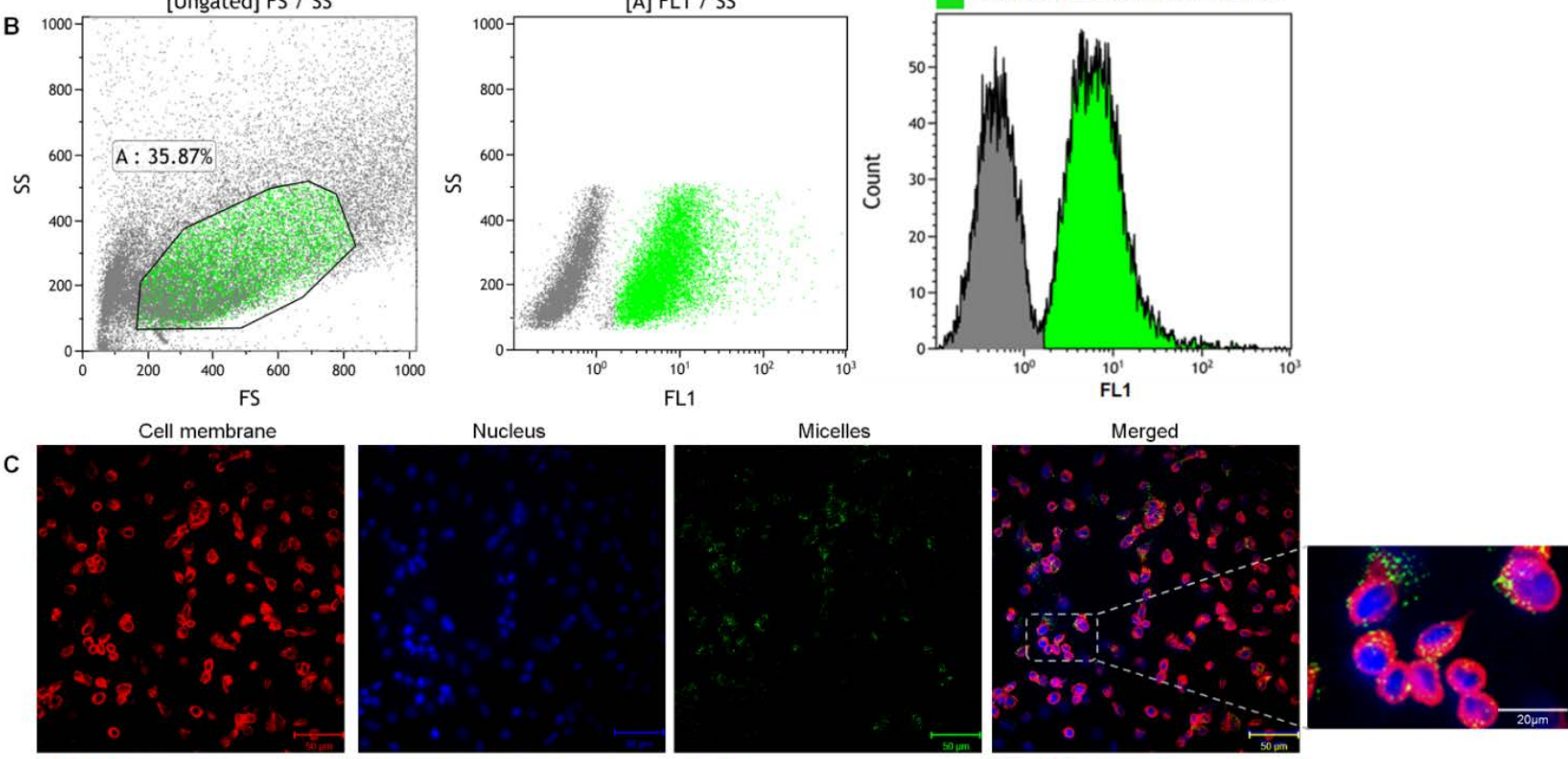

D
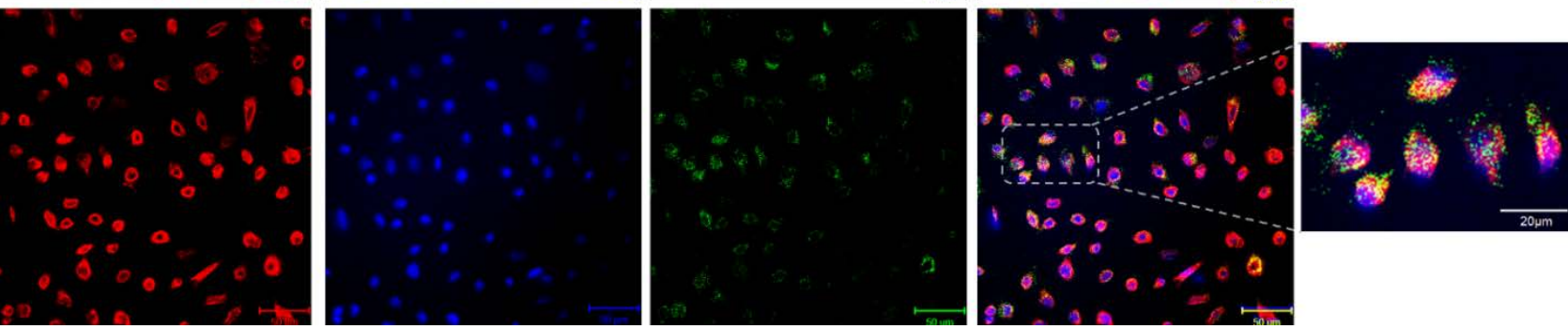

Fig. 5 Cellular uptake studies of micelles. (A) Fluorescence assisted cell sorting analysis of cellular uptake in MCF7 cells incubated with Oregon-green loaded uncrosslinked micelles, and (B) Oregon-green loaded core-crosslinked micelles. Cells incubated without micelles were used as a negative control to correct auto crosslinked micelles, and (D) Oregon-green loaded core-crosslinked micelles. Nuclei of cells were stained with Hoechst (blue fluorescence) and cell membranes were stained with CellMask ${ }^{\mathrm{TM}}$ deep red plasma membrane stain (red fluorescence).

proportion of apoptotic and dead cells even at moderate concentrations of $23 \mu \mathrm{g} / \mathrm{mL}$ equivalent of MTX, showing $50 \pm 9$ and $39 \pm 11 \%$ apoptotic and dead cells, respectively (Fig 8D). Higher concentrations of MTX-loaded core-crosslinked micelles $(50 \mu \mathrm{g} / \mathrm{mL}$ equivalent of MTX) were very effective against MCF7 cells ( $82 \pm 12 \%$ dead cells). Assays in which cells were treated with free MTX control $(50 \mu \mathrm{g} / \mathrm{mL})$ resulted in fewer apoptotic (approximately $15 \pm 4 \%$ ) and dead cells ( $\pm 3 \%$ ), as shown in Fig. S14B and S14C. The findings obtained from annexin V-
FITC/PI assay were thus in agreement with Hoechst/PI double staining and MTT assays.

To investigate the probability that low in vitro cytotoxicity of free MTX could be due to its poor aqueous solubility and reduced permeability, assays with MTX-DMSO controls were performed. The various concentrations of MTX dissolved in DMSO-medium were incubated with MCF7 cells for 48 hours. The results are shown in Fig. S15. Interestingly, there was no significant difference found in the apoptotic activity 

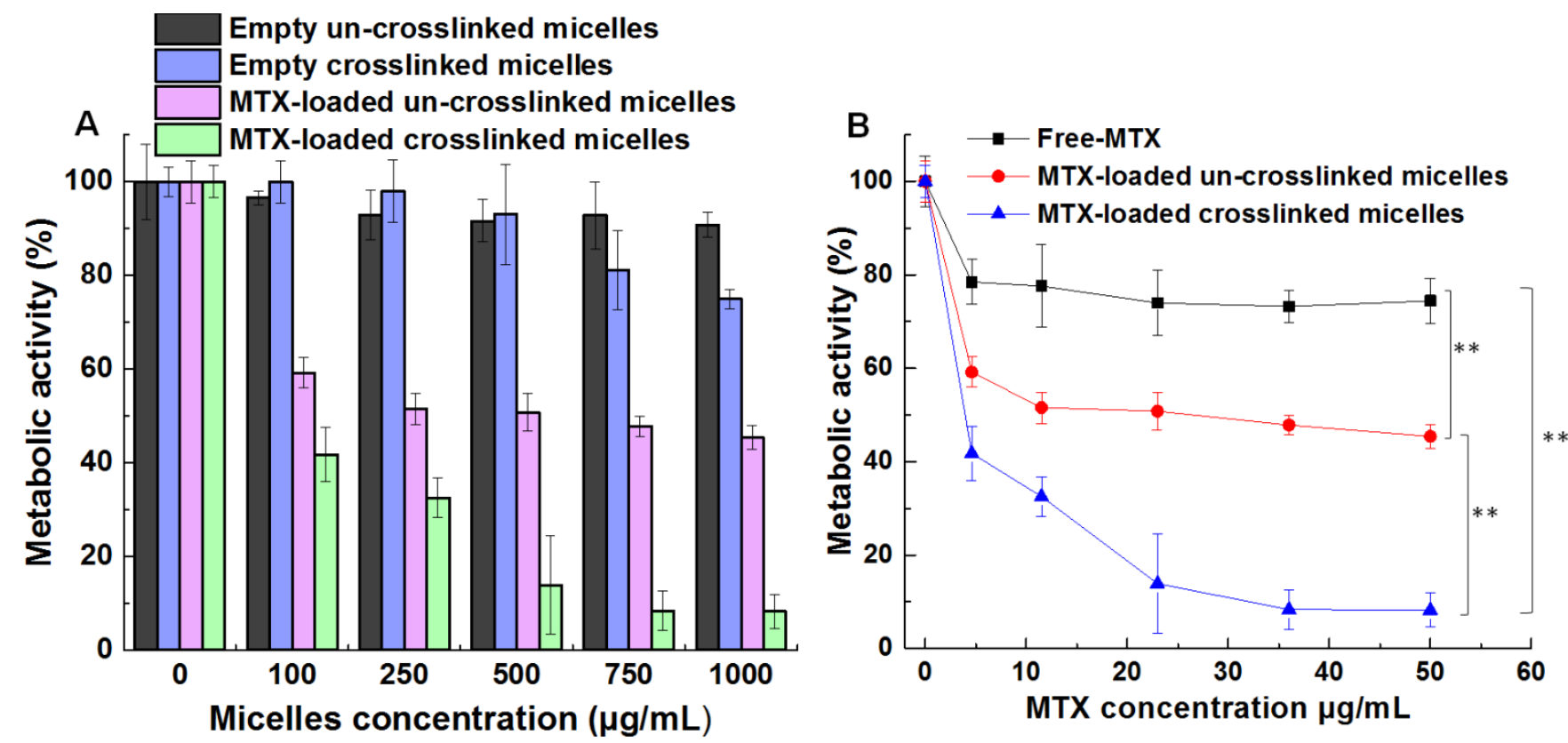

Fig. 6 Cytotoxicity analysis of micelles cultured with MCF7 cells for 48 hours. (A) Cytotoxicity of Empty and MTX-loaded un-crosslinked and core-crosslinked micelles, and (B) Metabolic activity of MCF7 cells as a function of MTX concentration. Error bars showing standard deviation ( $n=3$ ). MTT assays were used to analyse the metabolic activity of MCF7 cells. ${ }^{*}=$ significant $(p<0.05)$ and ${ }^{* *}=$ very significant $(p<0.01)$

as compared with free MTX (without DMSO) as a positive control.

\section{Discussion}

In this study, a synthesized $\alpha$-chloro- $\varepsilon$-caprolactone monomer was used as a precursor to generate functional amphiphilic block copolymer of mPEG-b-poly $(\varepsilon \mathrm{CL}-c o-\alpha \mathrm{Cl} \varepsilon \mathrm{CL})$ via ring opening polymerization. This amphiphilic block copolymer, with a narrow molecular weight distribution, was then substituted at the pendant chloro-alkyl positions with azides to obtain a 'clickable' block copolymer. Methotrexate (MTX)-loaded redoxresponsive reversible core-crosslinked micelles were then derived from this mPEG-b-poly $\left(\varepsilon C L-c o-\alpha N_{3} \varepsilon C L\right)$ block copolymer and formulated using a dialysis method.

In order to concentrate the bis-alkyne ethyl disulfide crosslinker in the hydrophobic part of the micelles, the crosslinker was directly added in the organic phase during micelles formation along with the copolymer and MTX. Upon drop-wise addition of this mixture into water, it was intended that the bis-alkyne ethyl disulfide crosslinker and MTX would be retained in the hydrophobic region of the micelles. However, the crosslinker still be accessible to $\mathrm{Cu}(\mathrm{I})$ ions when the click reaction proceeded between the pendant azide groups of the copolymer backbone and the alkyne groups of the crosslinker as the DMSO and aqueous phases mixed.

The MTX-loaded core-crosslinked micelles were larger than their un-crosslinked counterparts as shown in Fig. 3. The larger sizes of the core-crosslinked micelles were likely due to the accumulation of crosslinker in the hydrophobic core of micelles. Moreover, conformational rearrangements driven by triazole ring formation, which in turn caused decreased free movement of the chains of the copolymer, could also contribute to larger cores of the micelles, as has been reported previously. ${ }^{27}$

The hydrodynamic diameters of micelles in all the formulations as measured by DLS were larger than those of the air-dried micelles measured with TEM, as expected based on the hydration of the polyethylene glycol shell of the copolymeric micelles in solution. The zeta potential measurements showed near to neutral surface charges of the micelles (Fig. S8), again attributable to the neutral hydrophilic PEG shell that extended out into the aqueous phase and inhibited the aggregation of micelles through steric stabilization.

The drug loading studies of core-crosslinked micelles revealed that the crosslinking step increased the drug contents compared to the un-crosslinked micelles. The better encapsulation efficiency of crosslinked micelles could be attributed to a more tightly packed core with interconnected networks of crosslinked bridges providing more effective diffusion barriers to egress of MTX from the formulation. Various factors have been reported to influence drug loading of polymeric micelles including polymer-drug compatibility, ${ }^{42}$ size of the micelle core, ${ }^{43}$ presence and extent of micellar crosslinking, presence of specific functional groups in the copolymer, ${ }^{44}$ and molecular weight and chemical structure of the encapsulated agents.

From the in vitro release experiments (Fig. 4), it was apparent that un-crosslinked micelles showed greater burst release of MTX compared to core-crosslinked micelles. The latter retained most of the drug payload in the absence of exogenous reducing agent, however, rapid release of MTX was observed in reducing environments for the disulfide 

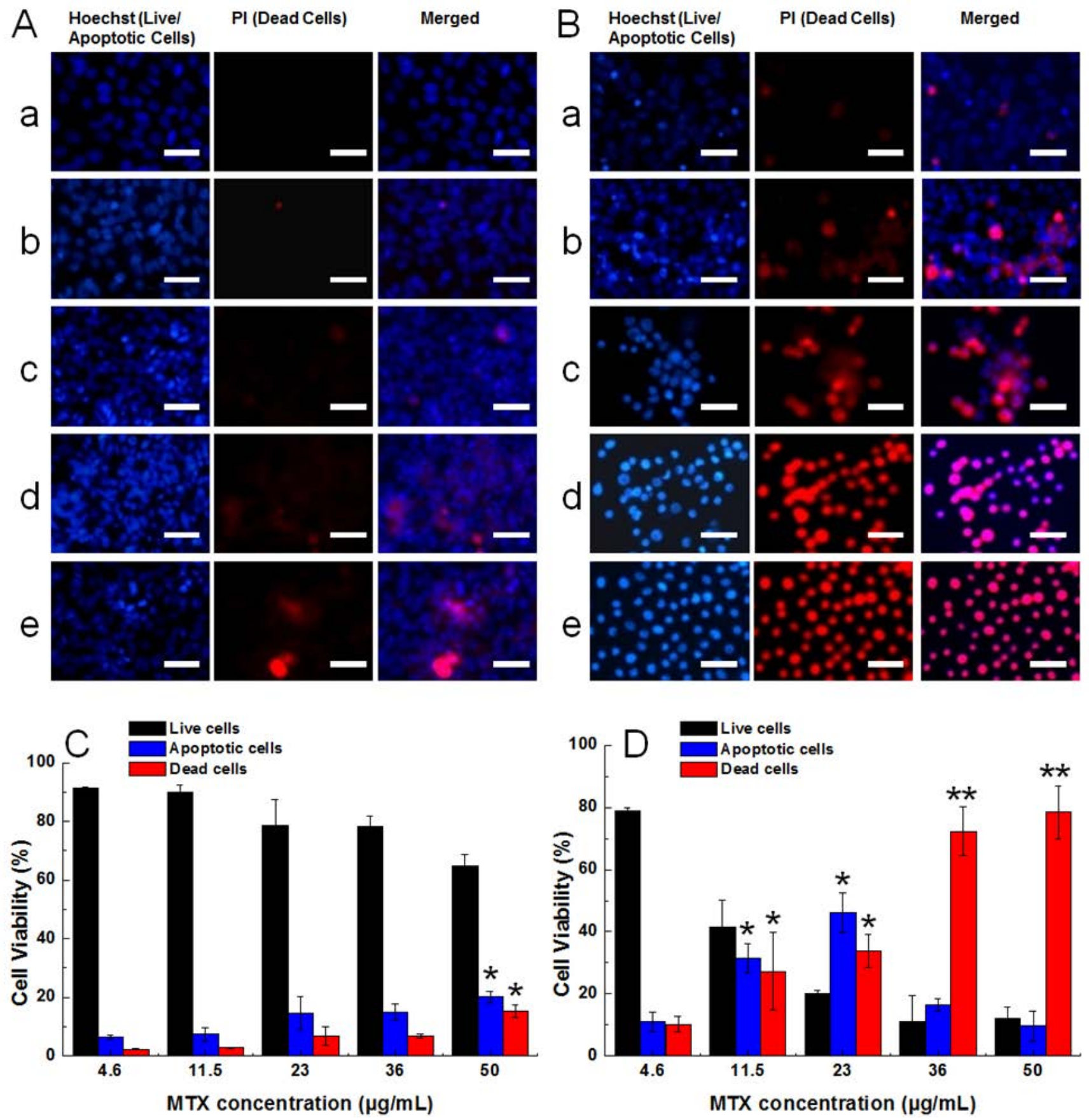

Fig. 6 Fluorescence microscopic analysis of apoptotic and dead cells in MCF7 breast cancer cells treated for 48 hours with (A) MTX-loaded un-crosslinked micelles and (B) MTX-loaded core-crosslinked micelles. a, b, c, d, and e, represent the MTX-loaded formulations equivalent to various amounts of free MTX (4.6, $11.5,23,36$ and 50 $\mu \mathrm{g} / \mathrm{mL}$, respectively). Hoechst 33342 dye was used to detect live and apoptotic cells, whereas propidium iodide (PI) was used to detect dead cells. Scale bars $\sim 40 \mu \mathrm{m}$. (C-D) Quantification of live, apoptotic, and dead cells in MCF7 cells treated with MTX-loaded un-crosslinked micelles and MTX-loaded core-crosslinked micelles, respectively. The percentage of live, apoptotic and dead cells was calculated by Infinity Analyze software. Error bars represent standard deviation $(n=3) . *=$ significant
$(p<0.05)$ and $* *=$ very significant $(p<0.01)$.

crosslinked polymer micelles. Various factors are known to affect the drug release from polymeric micelles such as polymer degradation, wettability, molecular weights of hydrophilic and hydrophobic blocks, glass transition temperature, binding affinity between the drug and copolymer. ${ }^{45}$ The incorporated drug may accumulate at various places inside the micelle $e . g$. at the interface between the core and shell of the micelle, within the micelle-core and to a lesser extent within the corona or shell of the micelle. Therefore, the localization of the drug within the micelle can also play an important role in the release kinetics of the encapsulated drug.

In this study, MTX release rate was not expected to be influenced by polymer degradation owing to the known slow hydrolysis rate of PCL. While the polymers were designed to be ultimately biodegradable, as PCL itself is broken down by esterolytic cleavage, ${ }^{46,47}$ we also intended for the polymer main 
chains to be stable enough over the time period of cell culture experiments such that any drug release resulting from disulfide cleavage would be immediately detectable above any drug liberated by 'background degradation' of PCL components. Prior reports have shown that PEG-PCL co-polymer micelles similar to those prepared in this study decreased in molar mass by $6 \%$ over a 12 week period in PBS. ${ }^{48}$ Thus we were confident

a
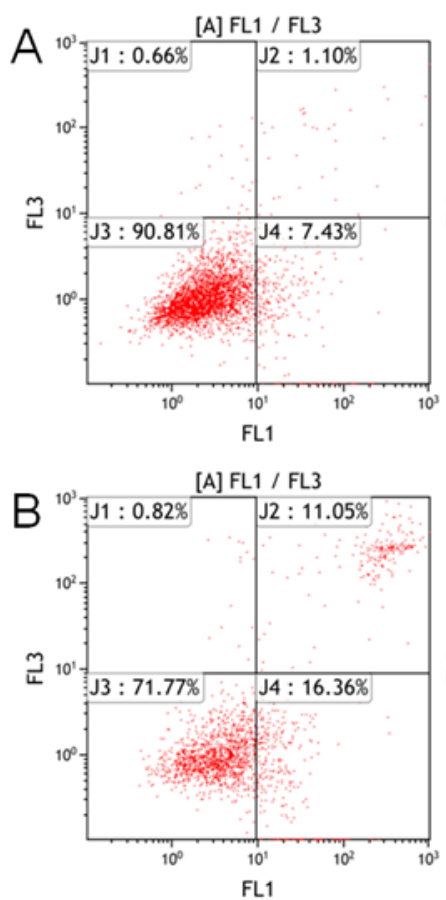

FL1 b

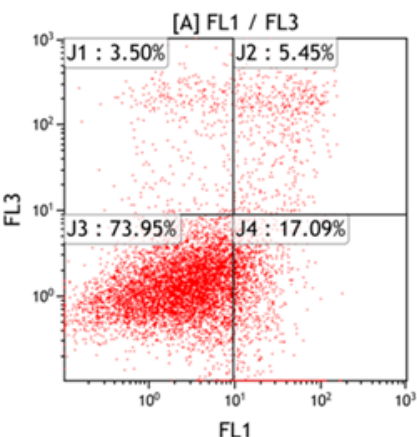

A] FL1 / FL3

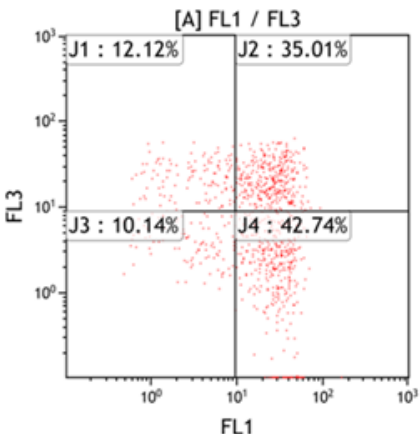

that backbone degradation would be much slower than crosslink cleavage due to disulfide reduction. Therefore, the initial 'burst release' from un-crosslinked micelles was likely to have been due to the rapid contact of the aqueous medium with a fraction of MTX localized on the corona or at the interface between the corona and micelle-core.

C
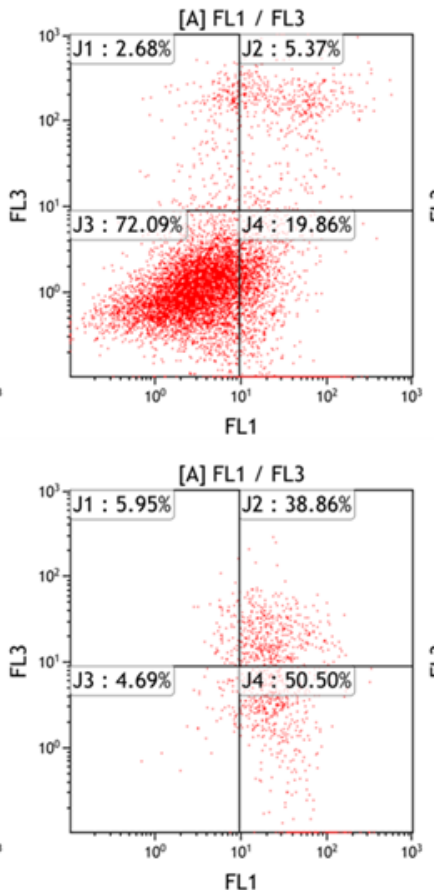

d
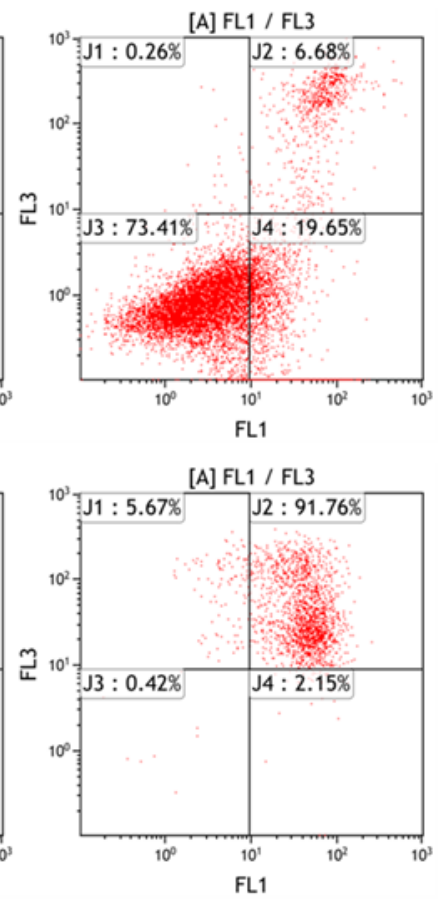
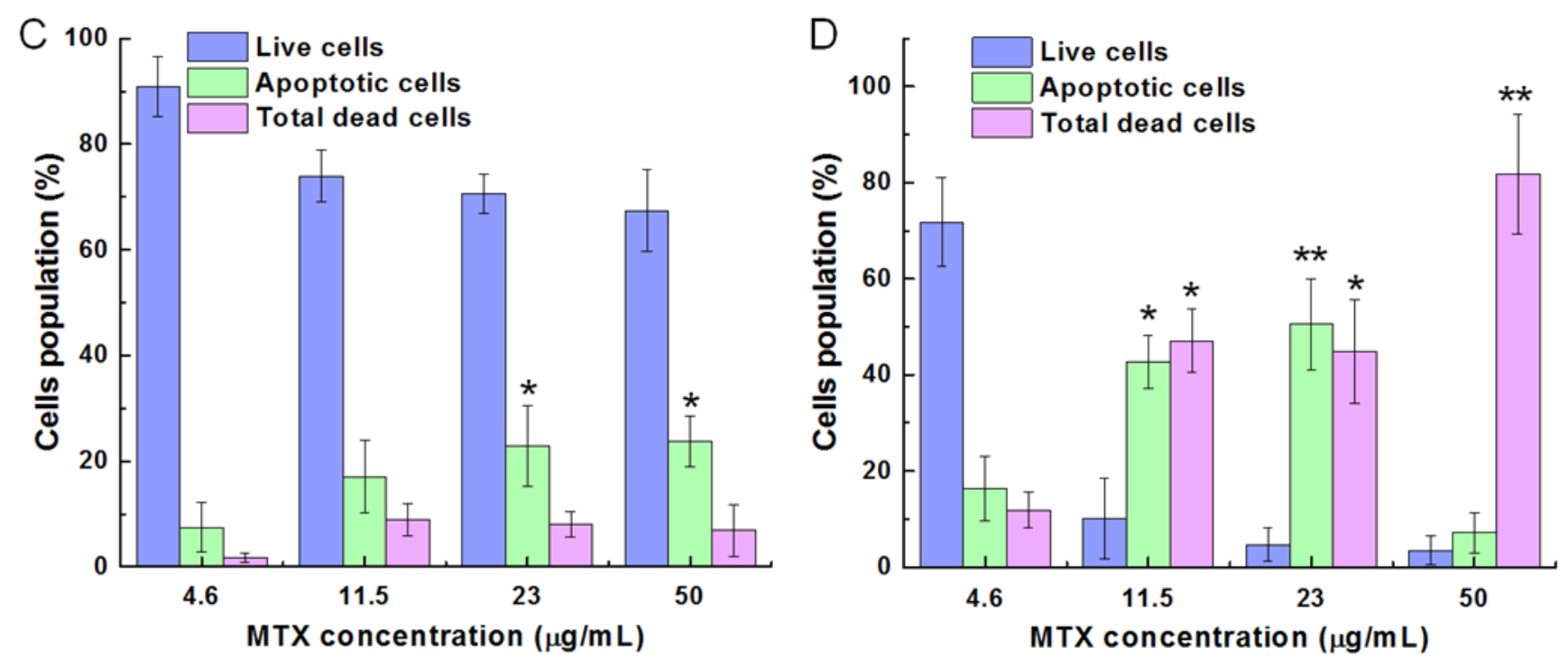

Fig. 7 Annexin V-FITC/PI assays to measure the apoptotic and dead cells in MCF7 breast cancer cells cultured with (A) MTX-loaded un-crosslinked micelles, (B) MTXloaded core-crosslinked micelles. a, b, c, and d represent the MTX concentration in micelles $(4.6,11.5,23$, and $50 \mu \mathrm{g} / \mathrm{mL}$, respectively). J1 $\sim$ necrotic cells, J2 $\sim$ dead crosslinked micelles and MTX-loaded core-crosslinked micelles, respectively. ${ }^{*}=$ significant $(p<0.05)$ and ${ }^{* *}=$ very significant $(p<0.01)$.

The steady or temporal drug release phase was probably due to the drug diffusion from the micelle-core into the release medium, as previously described. ${ }^{49}$ In contrast, MTX-loaded core-crosslinked micelles released lower amounts of drug under non-reducing conditions showing that core-crosslinked micelles more efficiently contained the drug payload compared to the un-crosslinked systems. 
The fast MTX release from core-crosslinked micelles under a reducing environment was likely due to the cleavage of disulfide bridges resulting in de-crosslinking and 'opening' of the micellar cores. Overall, redox-responsive reversibly core-crosslinked micelles efficiently restricted MTX release in non-reducing buffer conditions, however, introduction of DTT into the micellar suspensions caused cleavage of the internal micelle crosslinks, which subsequently facilitated drug release.

Analysis of the cellular uptake of the micelles was performed using Oregon-green as a fluorescent probe. Oregon-green loaded un-crosslinked and core-crosslinked micelles were efficiently taken up by MCF7 cells and there was no significant difference found in the magnitude of the cellular uptake of both type of micelles, as observed by flow cytometry (Fig. 5A and 5B, respectively) and confocal microscopy studies (Fig. 5C and Fig. $5 D$, respectively). However, confocal microscopy revealed that un-crosslinked micelles were mostly localized in cytoplasmic regions of the MCF7 cells, whereas, core-crosslinked micelles were accumulated both in the cytoplasmic and in perinuclear regions of MCF7 cells.

It has been reported that nanocarriers can penetrate into certain solid tumours due to the leaky vascular system existing in these types of cancer tissues. This phenomenon is known as the enhanced permeability and retention (EPR) effect, ${ }^{50}$ and has been shown to allow materials above a hydrodynamic volume threshold to partition selectively from the circulation into tumour tissue. If, after penetrating the target site, the retained nanocarriers can release a drug payload in the vicinity of cancer cells, an effective localisation of drug can be obtained, which is better in terms of the therapeutic window for the drug. In addition, many tumours lack effective lymphatic drainage, hence increasing the retention of nanoscale drug delivery systems in the target site. ${ }^{51}$ This retention of nanocarriers contributes to the further accumulation of the drug at the tumour locality. Polymeric micelles are considered to be good candidates to take advantage of the EPR effect due to the possibility that micelle-size can easily be tuned by controlling the molecular weights of hydrophilic and hydrophobic blocks and other parameters.

In any clinical application, drug-loaded nanocarriers must pass through various transport barriers to reach their targets. Specifically, translocation of injected drug delivery systems across the plasma membrane barrier is a prerequisite. Plasma membranes play an important role in control of cellular communication and cell division regulated by endocytosis. It can be assumed that cellular uptake of Oregon-green loaded un-crosslinked and core-crosslinked micelles was through passive caveolin-mediated endocytosis, as no targeting ligands were grafted to the micelles.

Thus, after being internalized, the micelles were likely to have been entrapped into endocytic vesicles, and trafficked into endo/lysosomal compartments. The endosomes and lysosomes are acidified vesicles containing multiple enzymes that can degrade certain foreign material.52, 53 In this study, the localization of Oregon-green loaded un-crosslinked micelles mostly in the non-nuclear regions of the MCF7 cells was likely to be attributable to the dis-assembly of micelles, and ultimately release of Oregon-green in the endosomes or lysosomes. This might have restricted the un-crosslinked micelles or Oregon-green to the cytoplasmic regions of the MCF7 cells. In control experiments in which MCF7 cells were treated with free Oregon-green, we found that the unencapsulated dye mostly accumulated in the plasma membranes or cytoplasmic regions of MCF7 cells (Fig. S16). This was most likely due to the relatively low aqueous solubility and cell membrane affinity of Oregon-green. ${ }^{54}$ In contrast, both micelle types internalised more efficiently than the free dye, but the crosslinked micelles may have been able to survive lysosomal degradation to a greater extent due to better colloidal stability and more robust cores. This might in turn have enabled more rapid transport out of lysosomal compartments, passage into the cytosol and transport or facilitated delivery of Oregon-green to the nuclei of MCF7 cells. ${ }^{41}$ The transport of nanocarriers into the cell nucleus is a complex phenomenon involving nuclear pore complexes and passive diffusion or receptor-regulated nuclear transport mechanisms. ${ }^{55}$ Experiments to probe these mechanisms with the cross-linked micelles are currently in progress.

The metabolic activity investigations using MTT assays showed that empty un-crosslinked and core-crosslinked micelles were essentially non-toxic to MCF7 cells. In contrast, MTX-loaded formulations significantly enhanced the cytotoxicity of MTX (Fig. 6A-B). Specifically, MTX-loaded core-crosslinked micelles were found to be more toxic to breast cancer cells as shown by the declined cell viability of $8.2 \%$ at $50 \mu \mathrm{g} / \mathrm{mL}$ equivalent to MTX, as compared with same concentrations of free-MTX (74 \% cell viability) and MTX-loaded un-crosslinked micelles ( $45 \%$ cell viability).

In order to confirm whether the cell death in tumour cells treated with MTX-loaded formulations was due to the onset of apoptosis, confirmatory tests were implemented. Typically, the initiation of apoptosis in cells results in condensation or fragmentation of chromatin due to the condensed nuclei of apoptotic cells, which can be detected by fluorescence microscopy using a cell permeable nucleic acid labelling blue fluorescent dye, Hoechst 33342. Concurrently, dead cells can be detected by staining with propidium iodide (a dye which exhibits strong fluorescence on DNA-binding). Propidium iodide cannot cross the membranes of live cells, however, dead or necrotic cells can be stained with PI due to their compromised cell membrane integrity. The MCF7 cells treated with MTXloaded un-crosslinked and core-crosslinked micelles, free MTX, and MTX-DMSO control showed characteristics features of apoptosis such as chromatin condensation and fragmentation, cell shrinkage, and formation of apoptotic bodies as shown in Fig. S17. Specifically, apoptotic nuclei clearly exhibited bright blue fluorescence with condensed or fragmented chromatin. The dead cells or the cells with late apoptosis stage showed pink fluorescence. The findings of the Hoechst/PI assays were consistent with the MTT assays, showing that MTX-loaded corecrosslinked micelles induced greater apoptosis and subsequently increased cell death in breast cancer cells, as compared with the free-MTX and MTX-loaded un-crosslinked micelles. 
It should be noted that free-MTX was less potent in inducing apoptosis as compared with the MTX-loaded nanocarriers. The low apoptosis inducing potency of free-MTX may have been a consequence of its low solubility in aqueous media. To investigate this phenomenon, a control experiment with MTX in DMSO was implemented, however, no apparent difference was found in induced apoptosis compared with MTX directly dissolved in cell culture media. These findings suggested that along with the low aqueous solubility, some other factors (e.g. low permeability and influx, higher efflux of MTX, and drug resistance etc.) could also be responsible for low cytotoxicity of free MTX. ${ }^{36,37}$ Comparison with the formulated sodium salt of MTX was not carried out, as for a breast cancer indication, the conventional oral methotrexate sodium tablet formulation would not be suitable.

To further confirm that cell death was induced via apoptosis (observed in the Hoechst/PI assays) by MTX-loaded formulations, annexin V-FITC/PI assays were performed. The findings of the annexin V-FITC/PI assay also revealed that MTXloaded core-crosslinked micelles induced apoptosis and finally death in tumour cells to a greater extent as compared with the MTX-loaded un-crosslinked micelles (Fig. 8) and free-MTX (Fig. S14). Therefore, the findings of annexin V-FITC/PI assays were in agreement with Hoechst/PI and MTT assays.

In order to achieve better therapeutic effects, anticancer drugs must be internalized into the cancer cells at high concentrations. In terms of passive transmembrane diffusion, repulsive interactions between the negatively charged plasma membrane and MTX may cause difficulties in permeation of free MTX into the cell membrane, consequently decreasing therapeutic effectiveness. Furthermore, after being transported into the cytosol, higher cellular levels of MTX must be maintained, since the affinity of dihydrofolate reductase enzyme is greater to folate than MTX. However, maintaining high intracellular levels of MTX is difficult due to the limited influx and spontaneous efflux of free MTX.

It is also worth noting that internalization of free MTX can occur via reduced-folate-carrier (RFC) mediated transport. ${ }^{56}$ The reduced-folate-carrier is an integral plasma membrane protein that mediates cellular transport of folates and antifolates (such as MTX). However, saturation of the reduced-folate-carrier at high MTX concentrations may occur which can inhibit the further uptake of the drug, therefore decreasing the therapeutic effectiveness. In contrast, MTX-loaded micellar formulations are assumed to follow a different path of internalization such as passive endocytosis, avoiding the potential issues of receptor saturation. In addition, the approximately neutral charge of MTX-loaded un-crosslinked and crosslinked micelles may not have induced repulsive interactions at the negatively charged plasma membranes. Therefore, uptake of MTX-loaded micellar formulations by endocytic routes might have been more efficient than diffusion of free MTX alone, hence enhancing the influx of MTX within MCF7 cells as compared to the reduced-folate-carrier route of free MTX. The low cytotoxicity of free MTX may have also been a consequence of its reduced intracellular retention, which can occur by P-glycoprotein-mediated drug efflux in addition to the normal folate metabolism and excretion pathways. Since no intracellular efflux pumps are known for co-polymer micelles, and most characterised efflux pumps are at least partially membrane-associated, the cytotoxic activity of MTX-loaded micelles may also have been enhanced by the lack of any efflux mechanisms for the regions of the cell to which MTX was delivered by the in-situ reduced micelles.

The findings of higher in vitro anti-cancer activity of MTX-loaded core-crosslinked micelles against MCF7 cells were consistent with the cellular uptake experiments. From internalization data, it could be deduced that MTX-loaded core-crosslinked micelles were more stable to dissociation both outside and inside the target cells. Thus the greater in vitro anti-cancer efficacy of MTX-loaded core-crosslinked micelles may have been due to the greater accumulation of MTX-loaded core-crosslinked micelles or release of MTX in cytoplasmic regions of MCF7 cells which were distant from efflux pump proteins. These data together suggest that further development of the redoxresponsive reversibly core-crosslinked micelles could be promising for tumour therapy and bioresponsive drug delivery applications. Experiments to evaluate the in vivo efficacy of these formulations are in progress.

\section{Conclusions}

In this study, functional micelles based on mPEG- $b$-poly $(\varepsilon \mathrm{CL}-c o-$ $\left.\alpha \mathrm{N}_{3} \varepsilon \mathrm{CL}\right)$ block copolymer were developed. An anticancer drug (methotrexate) was loaded into the hydrophobic cores of the micelles, which were further crosslinked by a redox responsive crosslinker to generate redox-responsive reversibly corecrosslinked micelles. The redox-responsive core-crosslinked micelles released lower amounts of the drug under simplified (serum free) physiological conditions, however, rapid drug release was observed in reducing environments. Corecrosslinked micelles were internalized by MCF7 cells quantitatively and mostly localized near the vicinity of cell nuclei. In contrast, un-crosslinked micelles were mostly localized in the cytoplasm of MCF7 cells. The cytotoxicity studies showed that empty un-crosslinked and core-crosslinked micelles were nontoxic to MCF7 cells. The MTX-loaded corecrosslinked micelles inhibited the metabolic activity of MCF7 in a dose dependent manner, as compared to the MTX-loaded uncrosslinked micelles and free MTX. The apoptosis assays revealed that MTX-loaded core-crosslinked micelles induced apoptosis and cell death in MCF7 cells to a greater extent as compared to the MTX-loaded un-crosslinked micelles and free MTX. Overall the data suggest that redox-responsive reversibly core-crosslinked micelles are promising candidates for diseaseactivated drug delivery applications.

\section{Acknowledgements}

The authors are grateful to the European Commission, Education, Audiovisual and Cultural Executive Agency, (EACEA) for an Erasmus Mundus grant to MG under the NanoFar Joint 
Doctoral Program. We also thank the CAPES (Brazilian Government) for a PhD scholarship (PM) and the Engineering and Physical Sciences Research Council (EPSRC) for financial support (Leadership Fellowship and Grant EP/H005625/1 to CA) and Doctoral Prize Fellowship to TM. CERM thanks the IAP VII05 (FS2) $^{\circ}$ for supporting this research. We gratefully acknowledge Christy Grainger-Boultby, Tom Booth and Paul Cooling for expert technical assistance.

\section{Data access statement}

All raw data created during this research are openly available from the corresponding author (cameron.alexander@nottingham.ac.uk) and at the University of Nottingham Research Data Management Repository (https://rdmc.nottingham.ac.uk/) and all analysed data supporting this study are provided as supplementary information accompanying this paper.

\section{Notes and references}

1. H. Cabral and K. Kataoka, Journal of Controlled Release, 2014, 190, 465-476.

2. L. M. Randolph, M.-P. Chien and N. C. Gianneschi, Chemical Science, 2012, 3, 1363-1380.

3. Q. Zhang, N. Re Ko and J. Kwon Oh, Chemical Communications, 2012, 48, 7542-7552.

4. T. Thambi, J. H. Park and D. S. Lee, Biomaterials Science, 2016, 4, 55-69.

5. S. Eliasof, D. Lazarus, C. G. Peters, R. I. Case, R. O. Cole, J. Hwang, T. Schluep, J. Chao, J. Lin, Y. Yen, H. Han, D. T. Wiley, J. E. Zuckerman and M. E. Davis, Proceedings of the National Academy of Sciences, 2013, 110, 15127-15132.

6. R. Duncan and M. J. Vicent, Advanced Drug Delivery Reviews, 2013, 65, 60-70.

7. R. Duncan and R. Gaspar, Molecular Pharmaceutics, 2011, 8, 2101-2141.

8. T. Lammers, F. Kiessling, W. E. Hennink and G. Storm, Journal of Controlled Release, 2012, 161, 175-187.

9. M. Talelli, M. Barz, C. J. F. Rijcken, F. Kiessling, W. E. Hennink and T. Lammers, Nano Today, 2015, 10, 93-117.

10. W. Scarano, P. de Souza and M. H. Stenzel, Biomaterials Science, 2015, 3, 163-174.

11. A. Duro-Castano, J. Movellan and M. J. Vicent, Biomaterials Science, 2015, 3, 1321-1334.

12. S. R. Abulateefeh, S. G. Spain, K. J. Thurecht, J. W. Aylott, W. C. Chan, M. C. Garnett and C. Alexander, Biomaterials Science, 2013, 1, 434-442.

13. E. Fleige, M. A. Quadir and R. Haag, Advanced Drug Delivery Reviews, 2012, 64, 866-884.

14. Z. Ge and S. Liu, Chemical Society Reviews, 2013, 42, 7289 7325.

15. E. K. Lim, T. Kim, S. Paik, S. Haam, Y. M. Huh and K. Lee, Chemical Reviews, 2015, 115, 327-394.

16. A. Acharya, I. Das, D. Chandhok and T. Saha, Oxidative Medicine and Cellular Longevity, 2010, 3, 23-34.

17. G. K. Balendiran, R. Dabur and D. Fraser, Cell biochemistry and function, 2004, 22, 343-352.
18. N. Ballatori, S. M. Krance, S. Notenboom, S. Shi, K. Tieu and C. L. Hammond, Biological Chemistry, 2009, 390, 191-214.

19. L. Flohé, Biochimica et Biophysica Acta (BBA) - General Subjects, 2013, 1830, 3139-3142.

20. B. Deng, P. Ma and Y. Xie, Nanoscale, 2015, 7, $12773-$ 12795.

21. A. R. Khan, J. P. Magnusson, S. Watson, A. M. Grabowska, R. W. Wilkinson, C. Alexander and D. Pritchard, Polymer Chemistry, 2014, 5, 5320-5329.

22. P. Theato, B. S. Sumerlin, R. K. O'Reilly and T. H. Epps, III, Chemical Society Reviews, 2013, 42, 7055-7056.

23. M. Soliman, R. Nasanit, S. R. Abulateefeh, S. Allen, M. C. Davies, S. S. Briggs, L. W. Seymour, J. A. Preece, A. M. Grabowska, S. A. Watson and C. Alexander, Molecular Pharmaceutics, 2012, 9, 1-13.

24. A. O. Saeed, J. P. Magnusson, E. Moradi, M. Soliman, W. X. Wang, S. Stolnik, K. J. Thurecht, S. M. Howdle and C. Alexander, Bioconjugate Chemistry, 2011, 22, 156-168.

25. G. Sicilia, C. Grainger-Boultby, N. Francini, J. P. Magnusson, A. O. Saeed, F. Fernandez-Trillo, S. G. Spain and C. Alexander, Biomaterials Science, 2014, 2, 203-211.

26. C. F. Riber, A. A. A. Smith and A. N. Zelikin, Advanced Healthcare Materials, 2015, 4, 1887-1890.

27. S. Cajot, N. Lautram, C. Passirani and C. Jérôme, Journal of Controlled Release, 2011, 152, 30-36.

28. H. S. Han, T. Thambi, K. Y. Choi, S. Son, H. Ko, M. C. Lee, D. G. Jo, Y. S. Chae, Y. M. Kang, J. Y. Lee and J. H. Park, Biomacromolecules, 2015, 16, 447-456.

29. H. Wang, L. Tang, C. Tu, Z. Song, Q. Yin, L. Yin, Z. Zhang and J. Cheng, Biomacromolecules, 2013, 14, 3706-3712.

30. H. Sun, F. Meng, R. Cheng, C. Deng and Z. Zhong, Antioxidants Redox Signal, 2014, 21, 755-767.

31. H. Lu, R. H. Utama, U. Kitiyotsawat, K. Babiuch, Y. Jiang and M. H. Stenzel, Biomaterials Science, 2015, 3, 1085-1095.

32. X. Jiang, S. Liu and R. Narain, Langmuir, 2009, 25, 1334413350.

33. Z. Zhang, L. Yin, C. Tu, Z. Song, Y. Zhang, Y. Xu, R. Tong, Q. Zhou, J. Ren and J. Cheng, ACS Macro Letters, 2013, 2, 4044.

34. J. Lv, H. Sun, Y. Zou, F. Meng, A. A. Dias, M. Hendriks, J. Feijen and Z. Zhong, Biomaterials Science, 2015, 3, 11341146.

35. B. Kumar, J. G. Meher, A. Gupta, V. K. Pawar, Y. Singh and M. K. Chourasia, Journal of Biomaterials and Tissue Engineering, 2014, 4, 700-709.

36. G. Yousefi, S. M. Foroutan, A. Zarghi and A. Shafaati, Chemical and Pharmaceutical Bulletin, 2010, 58, 147-153.

37. Y. Huang, J. Liu, Y. Cui, H. Li, Y. Sun, Y. Fan and X. Zhang, BioMed Research International, 2014, 2014, 904634.

38. R. Zhao, N. Diop-Bove, M. Visentin and I. D. Goldman, Annual Review of Nutrition, 2011, 31, 10.1146/annurevnutr-072610-145133.

39. F. M. Balis, J. Mirro, Jr., G. H. Reaman, W. E. Evans, C. McCully, K. M. Doherty, R. F. Murphy, S. Jeffries and D. G. Poplack, Journal of Clinical Oncology, 1988, 6, 1882-1886.

40. S. Cajot, P. Lecomte, C. Jerome and R. Riva, Polymer Chemistry, 2013, 4, 1025-1037.

41. Y. Lili, M. Ruihua, L. Li, L. Fei, Y. Lin and S. Li, International Journal of Pharmaceutics, 2016, 498, 195-204.

42. X. Ke, V. W. L. Ng, R. J. Ono, J. M. W. Chan, S. Krishnamurthy, Y. Wang, J. L. Hedrick and Y. Y. Yang, Journal of Controlled Release, 2014, 193, 9-26. 
43. C. Allen, D. Maysinger and A. Eisenberg, Colloids and Surfaces B: Biointerfaces, 1999, 16, 3-27.

44. J. Gou, S. Feng, H. Xu, G. Fang, Y. Chao, Y. Zhang, H. Xu and X. Tang, Biomacromolecules, 2015, 16, 2920-2929.

45. T. Niwa, H. Takeuchi, T. Hino, N. Kunou and Y. Kawashima, Journal of Controlled Release, 1993, 25, 89-98.

46. S. A. M. Ali, S. P. Zhong, P. J. Doherty and D. F. Williams, Biomaterials, 1993, 14, 648-656.

47. R. Ferrari, C. Colombo, C. Casali, M. Lupi, P. Ubezio, F. Falcetta, M. D'Incalci, M. Morbidelli and D. Moscatelli, International Journal of Pharmaceutics, 2013, 453, 551559.

48. B. Chu, L. Zhang, Y. Qu, X. Chen, J. Peng, Y. Huang and Z. Qian, Sci Rep, 2016, 6, 34069.

49. S. Y. Kim, I. L. G. Shin, Y. M. Lee, C. S. Cho and Y. K. Sung, Journal of Controlled Release, 1998, 51, 13-22.
50.

51.

52.

53.

\author{
5.
}

54.

55.

56.
Y. Matsumura and H. Maeda, Cancer Research, 1986, 46, 6387-6392.

V. P. Chauhan and R. K. Jain, Nat. Mater., 2013, 12, 958962.

K. Miyata, N. Nishiyama and K. Kataoka, Chem Soc Rev, 2012, 41, 2562-2574.

M. Elsabahy and K. L. Wooley, Chem Soc Rev, 2012, 41, 2545-2561.

W.-C. Sun, K. R. Gee, D. H. Klaubert and R. P. Haugland, The Journal of Organic Chemistry, 1997, 62, 6469-6475.

N. Panté and M. Kann, Molecular Biology of the Cell, 2002, 13, 425-434.

R. Zhao, N. Diop-Bove and I. D. Goldman, Molecular Pharmacology, 2014, 85, 310-321. 